\title{
Land application of sewage sludges: an appraisal of the US regulations
}

\section{Ellen Z. Harrison}

Cornell University Waste Management Institute, Center for the Environment, Rice Hall, Ithaca, NY, USA, 14853

(e-mail: EZH1@Cornell.edu)

\section{Murray B. McBride and David R. Bouldin}

Dept. of Soil Crop and Atmospheric Sciences, Cornell University, Bradfield Hall, Ithaca, NY, USA, 14853

\begin{abstract}
Current US federal regulations governing the land application of sewage sludges do not appear adequately protective of human health, agricultural productivity or ecological health. US standards are far less protective than those of many European countries and Canadian provinces. This is due to both policy choices such as a 'do no harm' philosophy applied in some northern European countries and also to many gaps and non-conservative assumptions in the risk assessment performed by US Environmental Protection Agency. The potential for widespread use of sludges on agricultural and residential land, the persistence of many of the pollutants, which may remain in soils for a very long time, and the difficulty of remediation support a cautious approach. Soil, water and crop characteristics in New York State and other areas of the northeastern US raise particular concerns. The authors do not suggest a prohibition of land application but, rather, significantly more restrictive use. Limiting cumulative additions of pollutants to prevent soils from exceeding recommended maximum contaminant levels can be achieved by application of clean sludges or by application of lesser amounts of less high quality sludges. Further investigation is needed to assess risks to ground and surface water and to establish standards for additional contaminants.
\end{abstract}

Keywords: land application, regulations, risk assessment, sewage sludge, soil standards, US EPA.

Reference to this paper should be made as follows: Harrison, E.Z., McBride, M.B. and Bouldin, D.R. (1999) 'Land application of sewage sludges: an appraisal of the US regulations', Int. J. Environment and Pollution, Vol. 11, No. 1, pp.1-36.

\section{Introduction}

Sewage sludges are created for a good reason - they are the byproduct of processes that clean our sewage before the cleaned water is discharged into streams and estuaries. New treatment processes hold promise for significantly reducing or eliminating sludge production but, until those are widely adopted, managing sludges is a necessity. There are currently limited options (ocean dumping has been banned in the US): landfilling, incineration, or application to the land.

The ban on ocean dumping and the environmental and economic costs of incineration and landfilling are part of what has led to increased focus on land application. Also, the philosophy of 'recycle what we can' is now widely held, and it is appropriate to contemplate recycling of sludges through land application.

Sewage contains not only human fecal wastes from homes and businesses but also products and contaminants from 
homes, industries, businesses, storm water, and landfill leachate (in some locales) and contaminants leached from pipes. The goal of sewage treatment is to clean up the water, so many contaminants are preferentially removed from the water and are concentrated in the sludges. Thus, for example, it is estimated that about $90 \%$ of the dioxins in the incoming water (influent) will end up in the sludges. Similarly, parasite eggs settle and are concentrated in sludges. This is beneficial in providing a cleaner effluent water discharge from the treatment plant, but makes beneficial use of the sludges more difficult.

There is general agreement that the long-term goal should be to recycle the nutrients and organic matter in sludges through land application, and there is agreement about the need to protect and enhance human, livestock and ecological health and the productivity of agricultural soils. Although the recycling of the organic matter and nutrients contained in wastewater through land application is a worthwhile objective, the mix of chemicals and pathogens in sludges includes contaminants that are detrimental to human health, agricultural productivity and ecological health. We believe that it is wise to be cautious, since many of these added contaminants are persistent and, once applied, will remain in soils and the ecosystem for many years.

\subsection{Is land application 'safe'?}

There is debate over whether recycling of sludges through land application as allowed under current US regulations is protective enough and whether it provides for a long-term sustainable practice. People often ask if land application is 'safe', but there is no such thing as 'safe'. Nearly all that we do entails some risk, so the question really is 'is the risk acceptable?'. People's acceptance of risk is subjective and depends in part on their basic values and beliefs as well as their training and experience. For example, some people place faith in technological solutions and our ability to calculate impacts and risks. Others are more sceptical, believing that history shows that there have been numerous failures of technology resulting in unanticipated environmental and health damage. These are fairly fundamental differences in world view, leading some to favour precaution while others are willing to proceed until harm is shown to occur. People's acceptance of land application also depends on their primary concerns (Table 1).

Table 1 Different concerns regarding land application of sludges.

\begin{tabular}{ll}
\hline Home gardener & Cost-effective product, risk to children \\
Grower & Reliable, cost-effective product, liability \\
Generators & Economical disposal/management \\
Neighbour & Nuisances, health, water contamination \\
Environmentalist & Ecological impacts, human health \\
Agronomist & Long-term soil productivity, plant growth \\
\hline
\end{tabular}

There is also an interesting difference in the time-scales over which people think. In the calculations performed for the risk assessment regarding land application of sludges, the United States Environmental Protection Agency (US EPA) used a 100 year site life. This may seem a long time to Americans whose view of history is relatively short and who have been used to having huge land resources, making it easy to consider 'moving on' to greener pastures if the need arises. However, the current agricultural lands in the US are substantially the same ones that we will be relying on for as long as humans continue to occupy the Earth.

In contrast, in Europe, the view of time and land is different, since one can see lands that have been farmed for thousands of years. Vineyards that grew grapes for Roman wines are still growing grapes today, and lead used by Romans 
persists in the soil two millennia later. That makes the concept of sustainable practices that can be carried out in perpetuity much more salient in Europe.

This is not to say that people have only one interest. The neighbour and environmentalist are also taxpayers concerned about economical sludge management. The generators and vendors depend on productive agriculture for a safe and economic food supply. But differences in the primary interest of different groups help to explain why intelligent, knowledgeable, concerned people can have very different views regarding land application (Citizens' Environmental Coalition and Scenic Hudson, 1996; Cornell Waste Management Institute, 1996; Cornell Waste Management Institute, 1997b; Water Environment Federation, 1996).

Thus there is disagreement about whether current regulations are stringent enough and whether today's sludges are clean enough for us to be confident that land application is a sustainable practice or at least an acceptable risk (McBride, 1995). Although US EPA asserts that application of sludges is a low risk and thus a low priority for their attention, this seems to ignore the fact that sludges may end up spread over large areas where we grow our food, obtain our water and where we live and play. The authors have particular concern for the application of the federal rules to New York State and other parts of the northeastern US where some soils have low $\mathrm{pH}$, which tends to increase metal availability, where a number of crops sensitive to phytotoxic metals are important, where soils are shallow, increasing concerns for groundwater contamination, and where dairy is the major agricultural use, raising concerns about molybdenum toxicity to ruminants, as well as concerns that the application of additional nutrients from sludges to those already provided by manure application may result in excessive nitrogen and phosphorus.

\subsection{The regulatory framework and federal standards}

The US EPA adopted regulations in 1993 (40 CFR Part 503, known as Part 503; US EPA, 1993; US EPA, 1994) that establish minimum standards that must be met if sludges are to be land-applied. The regulations include concentration limits for nine metals and for pathogens, and requirements for vector (flies and rodents) attraction reduction. The regulations establish Class A sludges, which have been treated to essentially eliminate pathogens (disease-causing organisms), and Class $\mathrm{B}$, in which pathogens have been reduced but are still present. Under the federal 503 rules certain site restrictions apply to Class B use, but no individual site permits are required for its use.

The federal regulations also establish standards for nine contaminants (Table 2). The standards include so-called 'exceptional quality' (EQ) sludges, which meet certain concentration limits (no more than $X$ parts per million of any of the nine regulated contaminants) as well as pathogen and vector reduction requirements. With regard to metal concentrations, sludges and sludge products that fail to meet one or more of those 'EQ' pollutant concentrations but which fall below a higher ceiling concentration may be applied, but the applicator is directed to keep track of the total amount of each metal applied and cease application when a regulatory cumulative pollutant loading limit is reached. Sludge products that fail to meet one or more of the 'EQ' pollutant concentrations but which fall below the ceiling concentration may still be distributed to homes or in bags as long as information on the acceptable annual pollutant loading rate (APLR) is provided to the user.

Table 2 Pollutant limits in US EPA Part 503 regulations.

\begin{tabular}{lcccc}
\hline Pollutant & $\begin{array}{c}\text { Pollutant } \\
\text { concentration in EQ } \\
\text { biosolids } \\
(\mathrm{mg} / \mathrm{kg}=\mathrm{ppm})\end{array}$ & $\begin{array}{c}\text { Ceiling conc. in } \\
\text { biosolids applied } \\
\text { to land }(\mathrm{mg} / \mathrm{kg})\end{array}$ & $\begin{array}{c}\text { Cumulative } \\
\text { pollutant loading } \\
\text { rate limits } \\
(\mathrm{kg} / \mathrm{ha})\end{array}$ & $\begin{array}{c}\text { Annual pollutant } \\
\text { loading rate } \\
(\mathrm{kg} / \mathrm{ha} / \mathrm{yr})\end{array}$ \\
\hline Arsenic & 41 & 75 & 41 & 2
\end{tabular}




\begin{tabular}{lrrrc} 
Cadmium & 39 & 85 & 39 & 1.9 \\
Copper & 1500 & 4300 & 1500 & 75 \\
Lead & 300 & 840 & 300 & 15 \\
Mercury & 17 & 57 & 17 & 0.85 \\
Molybdenum & - & 75 & - & - \\
Nickel & 420 & 420 & 420 & 21 \\
Selenium & 100 & 100 & 100 & 5 \\
Zinc & 2800 & 7500 & 2800 & 140 \\
Applies to: & $\begin{array}{l}\text { Bulk biosolids and } \\
\text { bagged biosolids }\end{array}$ & $\begin{array}{l}\text { All biosolids that } \\
\text { are land-applied }\end{array}$ & $\begin{array}{l}\text { Bulk non-EQ } \\
\text { biosolids }\end{array}$ & $\begin{array}{l}\text { Bagged biosolids } \\
\text { not meeting EQ } \\
\text { limits }\end{array}$ \\
\hline
\end{tabular}

Individual states within the US have the option of adopting regulations that are more stringent that the federal standards. New York state (NYS) regulations (Part 360; New York State Dept. of Environmental Conservation, 1993) have been more stringent in a number of ways, but NYS and many other states are considering revising or have revised their regulations bringing them closer to the federal Part 503 rules. Land application must follow the more stringent state rules where they exist.

Under the 503 rules, Class A 'EQ' sludges and sludge products can be applied without restriction in amount or duration, for use in home gardens, parks, crop production, etc. No record of where and how much is used is required to be kept, nor is notification of neighbours, local officials or others required. Under the federal rules there is also no permit requirement for a site where Class B sludges or sludges not meeting 'EQ' but falling below the ceiling limits are applied. Sludge products meeting Class A pathogen and vector reduction requirements but not meeting 'EQ' quality standards can be distributed to the public under the APLR requirements for labelling regarding maximum annual application as long as they fall below the ceiling limits.

A risk assessment was performed to establish the US EPA limits and to determine what contaminants to address (US EPA, 1996c). Since the regulations were adopted in 1993, the list of regulated contaminants has, in fact, been decreased with the elimination of chromium. Although a list of 31 additional contaminants was being considered for regulation in 'Round 2', US EPA is only planning to add regulation of co-planar PCBs and dioxins and furans to the list of nine regulated contaminants in the next several years.

\subsection{The US EPA risk assessment process}

The approach taken by US EPA to develop contaminant standards was to identify the various potential routes for exposure to sludge that is land-applied and then to assess the risks posed by each of these exposure pathways. Table 3 lists the 14 pathways that were assessed. The risk associated with each pathway was calculated for each of the contaminants for which the assessment was performed using available data. The contaminant standard for that particular contaminant was the number generated by the pathway resulting in the lowest concentration that represented an acceptable risk according to the US EPA analysis. That pathway was called 'the most limiting pathway' and, for the regulated contaminants, those pathways are listed in Table 4. Surprisingly to many, for five of the nine regulated contaminants the pathway of a child directly ingesting sludge was deemed to be the most limiting path, generating the lowest acceptable level. Each pathway was assessed independently and no attempt was made to look at the risk from exposure through several pathways simultaneously 
(US EPA, 1992; US EPA, 1995) or the effects of more than one contaminant at a time.

The remainder of this paper discusses the issues that lead the authors to recommend a more cautious approach to land application than that of the US EPA.

Table 3 Exposure pathways used in the Part 503 risk assessment.

\begin{tabular}{|c|c|c|}
\hline \multicolumn{2}{|c|}{ Pathway } & \multirow{2}{*}{$\begin{array}{l}\text { Description of highly exposed individual } \\
\text { Human (except home gardener) lifetime } \\
\text { ingestion of plants grown in sludge-amended soil }\end{array}$} \\
\hline 1 & Sludge $\varnothing$ soil $\varnothing$ plant $\varnothing$ human & \\
\hline 2 & Sludge $\varnothing$ soil $\varnothing$ plant $\varnothing$ human & $\begin{array}{l}\text { Human (home gardener) lifetime ingestion of } \\
\text { plants grown in sludge-amended soil }\end{array}$ \\
\hline 3 & Sludge $\varnothing$ human & Human (child) ingesting sludge \\
\hline 4 & Sludge $\varnothing$ soil $\varnothing$ animal $\varnothing$ human & $\begin{array}{l}\text { Human lifetime ingestion of animal products } \\
\text { (animals raised on forage grown on sludge- } \\
\text { amended soil) }\end{array}$ \\
\hline 5 & Sludge $\varnothing$ soil $\varnothing$ animal $\varnothing$ human & $\begin{array}{l}\text { Human lifetime ingestion of animal products } \\
\text { (animals ingest sludge directly) }\end{array}$ \\
\hline 6 & Sludge $\varnothing$ soil $\varnothing$ plant $\varnothing$ animal & $\begin{array}{l}\text { Animal lifetime ingestion of plants grown on } \\
\text { sludge-amended soil }\end{array}$ \\
\hline 7 & Sludge $\varnothing$ soil $\varnothing$ animal & Animal lifetime ingestion of sludge \\
\hline 8 & Sludge $\varnothing$ soil $\varnothing$ plant & $\begin{array}{l}\text { Plant toxicity due to taking up sludge pollutants } \\
\text { when grown in sludge-amended soils }\end{array}$ \\
\hline 9 & Sludge $\varnothing$ soil $\varnothing$ organism & Soil organism ingesting sludge/soil mixture \\
\hline 10 & Sludge $\varnothing$ soil $\varnothing$ predator & $\begin{array}{l}\text { Predator or soil organisms that have been } \\
\text { exposed to sludge-amended soils }\end{array}$ \\
\hline 11 & Sludge $\varnothing$ soil $\varnothing$ airborne dust $\varnothing$ human & $\begin{array}{l}\text { Adult human lifetime inhalation of particles } \\
\text { (dust) (e.g. tractor driver tilling a field) }\end{array}$ \\
\hline 12 & Sludge $\varnothing$ soil $\varnothing$ surface water $\varnothing$ human & $\begin{array}{l}\text { Human lifetime drinking surface water and } \\
\text { ingesting fish containing pollutants in sludge }\end{array}$ \\
\hline 13 & Sludge $\varnothing$ soil $\varnothing$ air $\varnothing$ human & $\begin{array}{l}\text { Human lifetime inhalation of pollutants in sludge } \\
\text { that volatilize to air }\end{array}$ \\
\hline 14 & Sludge $\varnothing$ soil $\varnothing$ groundwater $\varnothing$ human & $\begin{array}{l}\text { Human lifetime drinking well water containing } \\
\text { pollutants from sludge that leach from soil to } \\
\text { groundwater }\end{array}$ \\
\hline
\end{tabular}

Table 4 The limiting pathways according to the Part 503 risk assessment.

\begin{tabular}{ll}
\hline Element & Limiting pathway \\
\hline Arsenic & Child ingesting sludge \\
Cadmium & Child ingesting sludge \\
Copper & Plant phytotoxicity
\end{tabular}




\begin{tabular}{ll} 
Lead & Child ingesting sludge \\
Mercury & Child ingesting sludge \\
Molybdenum & Animal eating feed \\
Nickel & Plant phytotoxicity \\
Selenium & Child ingesting sludge \\
Zinc & Plant phytotoxicity \\
\hline
\end{tabular}

\section{Risk assessment}

A risk assessment is a model which, like all models, is a simplified simulation of real world conditions that relies of many assumptions and subjective judgements. Moreover, a model is only as good as the data from which it draw conclusions. The more complex the system being modelled, the more vulnerable the model and conclusions drawn from it are to errors resulting from the gaps between the model and reality. This is one reason why risk assessments generally fail to effectively evaluate impacts on ecosystems as a whole and do not address synergistic impacts.

Developing regulations for a country as diverse as the US is a tremendous challenge. The Part 503 risk assessment hold out the expectation that models approximating the reality of a ranch in west Texas are also appropriate for a vegetable farm in New York.

Because of the limitations inherent in a model, results should include an expression of their uncertainty, whether as a range of values or through the application of a safety factor. No such recognition of uncertainties are included in the US EPA risk assessment, contrary to more recent practices.

Although the US EPA and others made a major effort in performing the risk assessment supporting the Part 503 regulations, the authors of this paper demonstrate that there are fundamental errors in the assessment structure, a number of untenable assumptions made, and serious omissions (whether due to oversights or data gaps), which result in regulations that are not sufficiently protective. A precautionary approach such as that adopted by a number of other nations is more appropriate given the uncertainties inherent in such a complex risk assessment, potential long-term impact on agricultural productivity and the difficulty of remediating any impacts resulting from soil contamination. Many of the pollutants of concern are not degradable and may remain in the soil for an extremely long time, although the bioavailability of contaminants may limit their impacts.

\section{Comparison among different countries and comparison with cleanup standards}

Standards for sludges in a number of different countries are presented in Table 5. Comparisons require an understanding of how these maximum contaminant standards are applied. The standards in the top portion of Table 5 apply to products considered acceptable for use without significant restriction and are thus comparable. In general, home use of such products is permitted, though there may be some restrictions. Currently in NYS, for example, use in home vegetable gardens is not allowed.

For all contaminants except lead, the US EPA 'EQ' standards are significantly higher than standards for sludge products allowed elsewhere for unrestricted use. In fact, US EPA rules allow the application of sludges with metal concentrations up to the ceiling limits (Tables 2 and 5) to be used in home gardens. Under the APLR approach, US EPA regulations allow 
bagged products to be distributed as long as a label states the maximum annual application rate. This policy has been criticized even by those otherwise relatively positive towards land application (National Research Council, 1996; Chaney, 1995). Since children ingesting sludge is the limiting pathway for many of the 'EQ' contaminants (Table 4), application of sludges potentially containing up to the far higher ceiling concentrations of pollutants around homes seems inadvisable.

Sludges with contaminant concentrations listed in the bottom portion of Table 5 can be applied with some restrictions. To compare these standards and arrive at an understanding of what soil quality would result from application of a sludge, it is critical to know whether applications are limited in amount and frequency. So, for example, Ontario allows application of sludges that exceed the US EPA ceiling limit for a number of contaminants, but total application is limited to 40 metric tons/hectare or four applications. US EPA rules allow application of sludges with concentrations up to the ceiling limit, but for those not meeting EQ limits the total amount of any contaminant applied cannot exceed the cumulative limit (Table 2).

To facilitate a comparison among the standards, Table 6 shows the concentrations of the contaminants allowed in soils. Included in the table are calculated soil concentrations that would result from mixing an amount of sludge containing the cumulative limits of metals allowed under Part 503 and also under NYS Dept. of Environmental Conservation (NYS DEC) rules into the plough layer $(15 \mathrm{~cm})$. The actual metal levels would be higher, because background soil metal concentrations are not included in the calculations. Typical agricultural soil levels are included in Table 6 for comparison.

The cumulative pollutant loading allowed under Part 503 would result in contaminant levels approximately an order of magnitude higher than those allowed under rules in European countries (Table 6) (McGrath et al., 1994). Soil screening and clean-up numbers used by US EPA, NYS DEC and the Netherlands (intervention value) are also included. These US EPA and NYS values used in considering the need for remediation of contaminated sites are significantly lower than the values that sludge application would allow. NYS numbers are based on a goal of cleaning up sites to background concentrations (NYS DEC, 1994), whereas the US EPA numbers are based on an assessment of risks posed by soil ingestion and groundwater (US EPA, 1992). A site or soil background concentration is used when the risk-based number is lower than the background. The values for soil in other countries include both goals for soil quality and maximum levels allowed for contaminant accumulation, as noted in Table 6. 
Table 5 International sludge standards (values are $\mathrm{ppm}=\mathrm{mg} / \mathrm{kg}$ dry weight).

\begin{tabular}{|c|c|c|c|c|c|c|c|c|c|c|c|c|}
\hline & As & $\mathrm{Cd}$ & Co & $\mathrm{Cr}$ & $\mathrm{Cu}$ & $\mathrm{Hg}$ & Mo & $\mathrm{Ni}$ & $\mathrm{Pb}$ & $\mathrm{Se}$ & $\mathrm{Zn}$ & $\mathrm{PCB}$ \\
\hline \multicolumn{13}{|c|}{ Products relatively unrestricted } \\
\hline EPA EQ sludge ${ }^{1}$ & 41 & 39 & & & 1500 & 17 & & 420 & 300 & 100 & 2800 & \\
\hline Texas compost, home use $\mathrm{e}^{2}$ & $10^{3}$ & 16 & & 180 & 1020 & 11 & 75 & 160 & 300 & 36 & 2190 & 1 \\
\hline Ontario clean compost ${ }^{4}$ & 10 & 3 & & 50 & 60 & 0.15 & & 20 & 150 & & 500 & \\
\hline NYS Class 1 compost $^{5}$ & & 10 & & 100 & 1000 & 10 & & 200 & 250 & & 1000 & 1 \\
\hline \multicolumn{13}{|c|}{ Sludges applied with restrictions } \\
\hline EPA cciling limit sludge ${ }^{6}$ & 75 & 85 & & & 4300 & 57 & 75 & 420 & 840 & 100 & 7500 & \\
\hline NYS sludge $^{7}$ & & 25 & & 1000 & 1000 & 10 & & 200 & 100 & & 2500 & \\
\hline Denmark sludge $^{8}$ & $25^{9}$ & 0.8 & & 100 & 1000 & 0.8 & & 30 & $120(60)^{10}$ & & 4000 & \\
\hline Eur. Union sludge ${ }^{11}$ & & $20-40$ & & & $1000-1750$ & $16-25$ & & $300-400$ & $750-1200$ & & $2500-4000$ & \\
\hline Germany sludge $\mathrm{e}^{12,13}$ & & $5-10$ & & 900 & 800 & 8 & & 200 & 900 & & $2000-2500^{14}$ & 0.2 \\
\hline Ontario dewater ${ }^{15}$ & 170 & 34 & 340 & 2800 & 1700 & 11 & 94 & 420 & 1100 & 34 & 4200 & \\
\hline Ontario dewater, target ${ }^{16}$ & 35 & 4 & 77 & 530 & 380 & 1.4 & 1.2 & 80 & 220 & 6 & 840 & \\
\hline Sweden sludge, 1994 & & 4 & & 100 & 1200 & 5 & & 50 & 200 & & 800 & \\
\hline Sweden sludge, $1998^{17}$ & & 2 & & 100 & 600 & 2.5 & & 50 & 100 & & 800 & 0.4 \\
\hline Netherlands sludge ${ }^{18}$ & 0.15 & 1.25 & & 75 & 75 & 0.75 & & 30 & 100 & & 300 & \\
\hline Norway sludge ag ${ }^{19}$ & & 2.5 & & 100 & 1000 & 3 & & 50 & 80 & & 800 & \\
\hline
\end{tabular}




\section{Notes for Table 5}

${ }^{1}$ Unrestricted use if sludges contain less than these concentrations (US EPA, 1993).

${ }^{2}$ Standards for grade 1 compost suitable for home use. Different standards apply to agricultural use (TNRCC, 1997).

${ }^{3}$ Based on background soil. 1 ppm would be risk-based allowable concentration (TNRCC, 1996).

${ }^{4}$ Ontario Ministry, 1996.

${ }^{5}$ NYS DEC, 1993.

${ }^{6}$ Can apply until cumulative load is reached or, for bagged product that may be used anywhere, can apply at annual rate.

${ }^{7}$ NYS DEC Part 360.

${ }^{8}$ There are higher alternative limits for metals based on the ratio of metal to phosphorus and limits on application of phosphorus (Danish Ministry, 1996).

${ }^{9}$ As 25 for home garden use.

${ }^{10} \mathrm{~Pb} 60$ for home garden use.

${ }^{11}$ Upper value is max member country may allow, lower is recommended max (Leschber, 1997).

${ }^{12}$ Max 5 metric tons/ha/ 3 yrs (except compost, 10 metric tons/ha/ 3 yrs if concentration $<50 \%$ max). No use on fruit, vegetables, fodder crops, grazing land, forest.

13 Germany has liability fund to which all producers must contribute to reimburse farmers.

14 Value depends on $\mathrm{pH}$.

${ }^{15}$ Max four applications. Max 8 metric tons $/ \mathrm{ha} / 5 \mathrm{yrs}$ or $135 \mathrm{kgN} / \mathrm{ha} / 5 \mathrm{yrs} .40$ metric tons/ha max lifetime of site.

${ }^{16}$ Unspecified date, target values.

17 If concentrations are met may harvest crops one year after application. If exceed concentration, use only for energy or industrial crops. Organics are voluntary targets.

${ }^{18} 2$ metric tons/ha/yr max application rate. Sludge may be applied only if soils have less than specified concentration of metals (formula based on soil characteristics).

${ }^{19}$ Max sludge concentration for agricultural use (Miljoverndepartementet, 1997). 2 metric tons/10 yrs max application rate (Matthews, 1996) 
Table 6 International soil standards for metals (values are $\mathrm{ppm}=\mathrm{mg} / \mathrm{kg}$ ).

\begin{tabular}{|c|c|c|c|c|c|c|c|c|c|c|c|c|c|}
\hline & As & $\mathrm{Ba}$ & $\mathrm{Cd}$ & $\mathrm{Co}$ & $\mathrm{Cr}$ & $\mathrm{Cu}$ & $\mathrm{Hg}$ & Mo & $\mathrm{Ni}$ & $\mathrm{Pb}$ & $\mathrm{Se}$ & $\mathrm{Zn}$ & PCB \\
\hline Part 503 calculated sludged soil $^{1}$ & 20 & & 20 & & & 750 & 8.5 & & 210 & 150 & 50 & 1400 & \\
\hline EPA soil screening ${ }^{2}$ & 0.4 & 82 & 0.4 & $30 / \mathrm{SB}$ & $2^{3}$ & & & & 7 & 400 & 0.3 & 620 & $1^{4}$ \\
\hline $\begin{array}{l}\text { NYS calculated soil } \\
\quad(\text { ag soils classes } 1-3)\end{array}$ & & & 1.4 & & 138 & 35 & & & 14 & 138 & & 69 & \\
\hline $\begin{array}{l}\text { NYS calculated soil } \\
\quad(\text { ag soils classes 4-10) }\end{array}$ & & & 1.8 & & 205 & 52 & & & 21 & 205 & & 103 & \\
\hline $\begin{array}{l}\text { NYS calculated soil } \\
\text { (non-ag soils) }\end{array}$ & & & 4.6 & & & 115 & & & 69 & 460 & & 230 & \\
\hline NYS soil clean-up goals ${ }^{6}$ & $7.5 / \mathrm{SB}$ & $300 / \mathrm{SB}$ & $1 / \mathrm{SB}$ & & $10 / \mathrm{SB}$ & & $0.1 / \mathrm{SB}$ & & $13 / \mathrm{SB}$ & SB & $2 / \mathrm{SB}$ & $20 / \mathrm{SB}$ & \\
\hline Ontario soil ${ }^{7}$ & 14 & & 1.6 & 20 & 120 & 100 & 0.5 & 4 & 32 & 60 & 1.6 & 220 & \\
\hline Germany soil ${ }^{8}$ & & & $1-1.5^{9}$ & & 100 & 60 & 1 & & 50 & 100 & & $\begin{array}{l}150- \\
200^{9}\end{array}$ & \\
\hline Netherlands soil target ${ }^{10}$ & $29^{11}$ & 200 & 0.8 & 20 & 100 & 36 & 0.3 & 10 & 25 & 85 & & 140 & 0.02 \\
\hline Netherlands intervention ${ }^{12}$ & 55 & 625 & 12 & 240 & 380 & 190 & 10 & 200 & 210 & 530 & & 720 & 1 \\
\hline Norway soil ${ }^{13}$ & & & 1 & & 100 & 50 & 1 & & 30 & 50 & & 150 & \\
\hline Average N.Amer. ag soils & $6^{14}$ & & $0.1-0.3^{15}$ & & $15^{14}$ & $10-30^{15}$ & $0.05-0.1^{14}$ & $1-2^{14}$ & $10-30^{16}$ & $10-20^{15}$ & $0.3-0.4^{16}$ & $40-70^{16}$ & \\
\hline 95 percentile $\mathrm{N}$. Amer.ag soils & $10-20^{17}$ & & $0.78^{18}$ & & & $95^{18}$ & $0.3-0.4^{17}$ & $3.0^{17}$ & $57^{18}$ & $23^{18}$ & $1-1.5^{17}$ & $126^{18}$ & \\
\hline
\end{tabular}




\section{Notes for Table 6}

${ }^{1}$ Resultant soil conc. calculated when the cumulative load limit from Part 503 is mixed into the plough layer. Actual levels would be higher due to background level in soil.

${ }^{2}$ Generic soil screening levels based on human health risk assessment of soil ingestion and groundwater pathways. SB = soil background (US EPA, 1996).

${ }^{3} 2 \mathrm{ppm}$ listed for total chromium but concern is chromium(VI).

${ }^{4}$ Based on superfund guidance (US EPA, 1990).

${ }^{5}$ Resultant soil conc. calculated when cumulative load limit in Part 360 (NYS DEC, 1993) is mixed into plough layer. Actual levels would be higher due to background level in soil. Different cumulative limits are applied to different soil classifications.

${ }^{6} \mathrm{SB}=$ soil background (NYS DEC, 1994).

${ }^{7}$ Max soil conc. allowed includes background soil levels.

${ }^{8}$ No sludge additions to soils which exceed these levels.

${ }^{9}$ Depends on $\mathrm{pH}$.

${ }^{10}$ Desired soil quality. Values vary with clay and humus content.

${ }^{11}$ Netherlands TDIs are different from US, and within US values differ as well. For As the Netherlands value is 0.0021 vs. 0.0003 IRIS (US EPA database), vs. 0.0008 in 503. Netherlands risk assessment does not include groundwater path because there are essentially no private wells in Holland.

${ }^{12}$ Level at which clean up needs to be considered.

${ }^{13}$ Maximum soil concentration.

14 Value for southern Ontario soils (Frank et al., 1976).

15 NYS average values taken from Holmgren et al., 1993.

16 Typical US soils (Logan and Traina, 1993).

${ }^{17}$ Approximately $95 \%$ of Eastern US soils would fall at or below this value (Shacklette and Boerngen, 1984).

${ }^{18}$ Approximately $95 \%$ of US soils would fall at or below this value (Holmgren et al., 1993). 
All of these various soil levels are all far lower than those allowed under Part 503. The Dutch intervention values were derived using a pathway risk analysis similar to that used for Part 503, yet the values they suggest for soil clean-up of contaminated sites are generally as low or lower than those suggested by US EPA to pose no significant threat (McGrath $e t$ al., 1994).

\section{Alternative policy approaches}

The US rules allow sludges to be applied up to a maximum acceptable contaminant limit. In other words, through a risk assessment some contaminant level is selected as a maximum level to which people, crops or other receptors can be exposed without creating unacceptable harm (as defined by the assumptions in the risk assessment). Pollutants present in sludge may then be added up to that limit. Thus, if it is concluded that exposure to 50 micrograms per day of contaminant $\mathrm{X}$ through food is acceptable, the Part 503 rules calculate the maximum amount of contaminant $X$ that could be in sludge and not result in more than 50 micrograms per day in the diet. Obviously, many assumptions go into all phases of this calculation and under the Part 503 risk assessment, no safety factors were applied.

In contrast, several European countries (Sweden, Denmark, the Netherlands) use a philosophy of 'do no harm' to protect soil quality. Their approach to achieving sustainability is to work towards limiting inputs to the soil so they do not exceed outputs, thus preventing accumulation of pollutants in the soil (McGrath et al., 1994; Munters, 1997; Witter, 1996). The 'do no harm' philosophy of environmental management strives to limit the addition of contaminants to the levels that are present in uncontaminated soils while recognizing the inherent uncertainty involved in risk modelling. This "no net degradation' approach is precautionary - it permits land application of inorganic contaminants only to the extent to which there will be no accumulation above the levels in uncontaminated agricultural soils. In setting clean-up objectives for remediation of contaminated sites in NYS, this philosophy was embodied in the use of soil background numbers for the inorganic contaminants (Table 6) (NYS DEC, 1994).

Because there is a range of metals levels in uncontaminated soils resulting from differences in site geology and other factors, a limit may be set at the level found in no more than 5\% (or some other fraction) of such soils. Thus $95 \%$ of uncontaminated soils would have less than the regulated limit. Such a 'no net degradation' policy would result in levels for the nine regulated metals that are much lower than those established under Part 503 (Table 6).

The values for some elements determined through a risk assessment may be lower than those found in some uncontaminated soils. In examining arsenic, for example, a limit of $1 \mathrm{ppm}$ was determined through the risk assessment performed in Texas, whereas background levels in soils exceeded that number (TNRCC, 1996). This led Texas to adopt an arsenic standard of $10 \mathrm{ppm}$ based on the values in soils.

Some would suggest that calculations that show acceptable risk levels to be lower than background soil levels indicate that the risk assessments are overly conservative, and for some risk assessments the application of safety factors may provide a conservative margin. However, the inorganic elements present in soils may be significantly less bioavailable than those same elements added in sludge or other anthropogenic additions. The chemical form in which an element is present plays a critical role in its biological impact.

Because the concentration of contaminants allowed under the Part 503 regulations in the US in sludges applied to land is markedly greater than the agricultural soil concentrations (Table 6), over time the levels of any persistent contaminants, such as heavy metals will increase in soils to the level in the sludge being applied. Recent evidence, however, suggest that

losses of certain metals through leaching is not always negligible, so there may be removal of some fraction of the metals through groundwater (Camobreco et al., 1996; Richards et al., 1997). 


\section{Sludge quality}

Sewage sludges vary widely in the concentration of contaminants. Efforts to remove industrial contaminants through pretreatment have resulted in greatly improved quality over the last decade in the US. As shown in Table 7, the mean concentrations of the regulated contaminants in both the US and NYS sludges are far lower than the US EPA 'EQ' standards. In fact, $95 \%$ of NYS sludges fall far below those standards for most contaminants, indicating that stricter standards would be achievable today for most sludges.

Table 7 Metal levels in sludges (values are ppm).

\begin{tabular}{lccccccccccc}
\hline & $\mathrm{As}$ & $\mathrm{Cd}$ & $\mathrm{Cr}$ & $\mathrm{Cu}$ & $\mathrm{Pb}$ & $\mathrm{Hg}$ & $\mathrm{Mo}$ & $\mathrm{Ni}$ & $\mathrm{Se}$ & $\mathrm{Tl}$ & $\mathrm{Zn}$ \\
\hline $\begin{array}{l}\text { Part 503 'EQ' } \\
\text { standard }\end{array}$ & 41 & 39 & - & 1500 & 300 & 17 & - & 420 & 100 & 2800 \\
$\begin{array}{l}\text { US sludge } \\
\text { (mean) }\end{array}$ & 10 & 7 & 119 & 741 & 134 & 5 & 9 & 43 & 5 & 5 & 1202 \\
$\begin{array}{l}\text { NYS sludge } \\
\text { (mean) }\end{array}$ & 6 & 7 & 86 & 763 & 152 & 2.7 & 18 & 44 & 5 & - & 887 \\
$\begin{array}{l}\text { NYS sludge } \\
(95 \text { percentile) }\end{array}$ & 13 & 18 & 242 & 1600 & 403 & 7 & 57 & 110 & 9 & - & 1750 \\
\hline
\end{tabular}

$a$ Data from 1988 National Sewage Sludge Survey (US EPA, 1990).

$b \quad$ Data from early 1990s, (NYS DEC Division of Solid and Hazardous Materials).

Pollution prevention efforts in a number of European countries have greatly reduced contaminant concentrations and have resulted in sludges that are able to meet much more stringent limitations for cadmium ( $<2 \mathrm{ppm})$ (Madsen, 1997; Tidestrom, 1997b; Witter, 1996). Although control of industrial sources can help to reduce many contaminants, others, such as copper and lead, result in part not from industrial sources but from leaching of pipes, including those in our homes. Efforts to decrease the corrosivity of water supplies can help to reduce their concentrations. There is some evidence that low levels of dioxins come from residential sources (washing or textiles), which may make them difficult to control in sludges (Horstmann and McLachlan, 1995).

In addition to sludge quality improvement, wastewater treatment technologies that minimize sludge production are being developed, thus decreasing the need for disposal. Other technologies to recover energy or fuel gas from sludges also hold some promise for development of beneficial use options beyond land application.

\section{Alternative land application uses}

The significance of risks posed by land application of sludges varies according to different use scenarios. For example, because the potential for a child to ingest sludge is much greater for sludge used by residential gardeners than for sludge applied to field corn, stringent limitations based on this pathway should apply to home use but may not be necessary for agricultural use. Conversely, groundwater contamination may be a concern where sludges are applied to large acreage, but will not likely be a concern for smaller scale residential use. Although this paper focuses on the potential use of sludges on lands used for growing agricultural crops, there are numerous other land application scenarios that present less risk. Among 
these are application to turf such as golf courses, roadsides or parks, reclamation of severely disturbed lands, or application to biomass plantations. Development of different standards for different end uses would recognize the variation in risks and benefits and permit the use of sludges where most appropriate.

\section{Non-protective aspects of US EPA Part 503 risk assessment}

Discussed below are a number of the assumptions and decisions that are part of the US EPA risk assessment for Part 503 that the authors believe to be questionable and are not conservative or protective.

\subsection{Pollution allowed to reach maximum 'acceptable' level}

Through a risk assessment some contaminant level is selected as a maximum level to which people, crops or other receptors can be exposed without creating unacceptable harm (as defined by the assumptions in the risk assessment). Pollutants present in sludge may then be added up to that limit. For example, sludge application would be allowed to raise groundwater contaminant levels up to the drinking water standard or increase contaminants in crops up to the level considered to represent an acceptable risk. The philosophy behind this approach relies on an accurate knowledge of pollutant pathways, processes and impacts. The impact of other sources of pollutants (e.g. atmospheric deposition) and change over time in both pollutant inputs and knowledge of impacts (e.g. the hormone disrupting effects of some synthetic organic chemicals which is likely to result in a decrease in the allowable maximum contamination levels for those chemicals) makes this an uncertain and potentially non-protective approach. Without a very good understanding of pathways and processes, allowing pollutants to reach calculated maximum acceptable values is unwise. It leaves no room for the possibility that as our understanding of impacts increases, maximum acceptable values will be lowered (e.g., standards for lead have decreased over the years, our knowledge of hormone disruption impacts at low chemical concentrations is increasing). Once it has occurred, soil contamination is difficult to remediate. Alternative approaches are discussed in the section on alternative policy approaches above.

\subsection{No safety or uncertainty factors}

The uncertainties inherent in a risk assessment, originating from both missing data and a lack of understanding of how available data should be applied to complex systems with inherent biological variation, argue for the application of safety factors. Many risk assessment-based standards divide calculated numbers by 2, 10, 100 or even 1000 depending on the level of uncertainty or the applicability of available data. The Dutch risk assessment, for example, assigns uncertainty values of 1 , 2 or 3 based on the number and quality of data available for the particular variable being assessed (van den Berg, 1994).

\subsection{Evaluates each exposure pathway separately, not accounting for multiple pathways of exposure or synergy}

It is likely that in a number of sludge-use scenarios, a person or animal will be exposed simultaneously through a number of pathways. Thus the child of a home gardener using sludge will likely eat vegetables from the garden (pathway 2, Table 2) and may ingest soil that has received sludge (pathway 3). They may also drink from a well or eat animals or animal products that have been impacted by sludge use. The US EPA risk assessment calculated 'acceptable risk' according to each of 14 pathways and selected as a standard the lower of those numbers. They did not add exposures from several paths to arrive at 
a level from the multiple exposures which would result in an 'acceptable' risk. An additive approach is generally used in performing risk assessments (van den Berg, 1994; Duff, 1996; Lund, 1997).

Similarly, the risk assessment did not attempt to address the ways in which the effects of exposure to multiple chemicals simultaneously can affect the toxicity impacts. Although estimating exposure and risk to a single pollutant from a number of pathways simultaneously could be done by summing results from different pathways, our lack of knowledge about how different contaminants interact makes it infeasible to evaluate impacts resulting from exposure to multiple pollutants. There can be synergistic or antagonistic impacts in which exposure to multiple chemicals has a greater or less impact than exposure to each. Our very limited knowledge of how different contaminants may interact is one reason for scepticism regarding risk assessment and for the use of a more conservative approach.

\subsection{Calculates cancer risk of 1-in-10 000 vs. 1-in-1 000000}

US EPA made a policy decision that a cancer risk of 1-in-10 000 was an acceptable risk resulting from sludge application. For a number of contaminants, cancer risk was determined to be the most significant risk. A cancer risk estimated to lie between

1 -in-

10000 and 1-in-1 000000 is typically used in setting regulations and in many regulatory contexts (e.g. drinking water regulation), a risk of one excess cancer in one million people exposed is used to establish the standards. Under the Part 503 risk assessment, policy-makers elected to use the less restrictive value.

\subsection{Soil ingestion rate}

Children inadvertently ingesting sludge via the soil is calculated by US EPA to be the most restrictive pathway for five of the nine regulated metals (pathway 3, Table 3). The Part 503 risk assessment calculated risk for a child eating $200 \mathrm{mg} / \mathrm{day}$ of soil for 5 years. (For perspective, $200 \mathrm{mg}$ equates to about the volume of an aspirin tablet). Two aspects of this analysis may not be protective. First, the data regarding ingestion are limited and $200 \mathrm{mg}$ /day of soil may be low. Second, through normal activities, inadvertent ingestion continues throughout life, though at lesser rates (although rates may actually peak in teenage years). Other risk assessments include child ingestion rates for several years and a lower adult ingestion rate (the Dutch and Texas risk assessments use 50 and $100 \mathrm{mg}$ /day for adult ingestion [TNRCC, 1996; van den Berg, 1994] ) for the remaining lifetime.

All young children ingest some soil as part of their normal behaviour. The regulation seeks to protect the 'average highend child' (not defined). There are children who ingest far more than average (so-called pica children), and the regulation clearly states that it does not seek to protect these children.

A key piece of data is just how much soil children actually ingest. Collecting data on this is difficult and there are only a few studies to draw from. The primary study monitored 24 children for 8 days in Massachusetts. The range of each child and the day-to-day variation were large. The average rate derived was $200 \mathrm{mg} / \mathrm{day}$. However, there is no clear agreement on the appropriate statistical approach to extrapolating from these few children and few days to an annual rate for an 'average high-end child' (Stanek and Calabrese, 1995). Thus there is concern that the regulatory limits based on $200 \mathrm{mg} / \mathrm{day}$ soil ingestion may not be conservative enough to protect children who may be exposed, particularly in a home garden scenario. 


\subsection{Underestimates pollutant intake through food}

\subsubsection{Assessed diet very low in vegetables}

Dietary intake is a critical parameter for calculating risk from pathways 1 and 2. An average late 1970s diet was used in the risk assessment. Americans, responding in part to the USDA recommended diet, are eating significantly greater amounts of fruits and vegetables. Recalculations based on the USDA recommended diet of the risk associated with eating from a home garden receiving sludge show that the US EPA standard for cadmium would exceed the 'acceptable' daily intake.

US EPA assessed two scenarios, one for the general population and a second for the home gardener. The risk assessment assumes $2.5 \%$ of the vegetables eaten by the general population were grown on sludge-amended soils. While this may be a reasonable guess for the nation as a whole, states with high populations, such as NYS, may ultimately have a much higher proportion of sludged agricultural land, though how this relates to the percentage of a person's diet depends greatly on how locally their food is obtained. The recent trend for consumers to buy 'shares' in produce from a given farm could expose some individuals much more than the average, though less than the home gardener. For the home gardener, the US EPA assessment assumes $59 \%$ of most vegetables eaten are grown in the home garden which received sludge.

Dietary assumptions used in the risk assessment make use of what the average American ate in the late 1970s for both the general population evaluation and for the home gardener evaluation (US EPA, 1992). This diet is very low in fruits and vegetables, and the population is now eating more of these components of the diet that contribute the majority of cadmium intake (Chou, 1991; Heirmendinger and van Duyn, 1995; Krebs-Smith et al., 1995). In particular, home gardeners can be expected to eat significantly more vegetables than the average American.

A comparison was made of the diet evaluated in the US EPA risk assessment and of the diet recommended by USDA in the food pyramid (USDA, 1996). The total amount (in dry weight) of vegetables, fruits and grains recommended by USDA is about two and a half times that used by US EPA (Table 8). For leafy vegetables, which are a major source of dietary cadmium, the US EPA diet is one-sixth of the USDA recommended amount. The recommended diet contains more than 16 times the amount of fruit as the US EPA diet used in the Part 503 risk assessment. 
Table 8 Comparison of diet used in US EPA risk assessment and diet recommended by USDA.

\begin{tabular}{lccc}
\hline & ${\text { US EPA } 503^{a}}^{a}$ & USDA recommended $^{b}$ & Ratio USDA/EPA $^{\text {Grain }}$ \\
Leafy vegetable & 90.7 & 186.8 & 2.1 \\
Roots & 2.0 & 11.7 & 5.9 \\
Potato & 1.6 & 9.3 & 5.8 \\
Fruit/garden fruit & 15.6 & 25.6 & 1.6 \\
Total & 4.2 & 69.9 & 16.8 \\
\hline
\end{tabular}

a US EPA is average diet for $70 \mathrm{~kg}$ male in late $1970 \mathrm{~s}$.

$b$ USDA is recommended 2200 calories diet. The four vegetable servings are assumed to be 1 potato, 2 leafy veg., 1 root.

Because the sludge-soil-plant-human pathway risk analysis depends on the amount of fruits, vegetables and grains consumed, revising dietary assumptions leads to very different standards. For example, using US EPA's assumptions and calculating allowable application for cadmium, changing only the dietary assumptions to those of the food pyramid, leads to a standard for cadmium of $15 \mathrm{ppm}$, compared with the current federal standard of $39 \mathrm{ppm}$. Even this may not be protective, as discussed below.

\subsubsection{Very low plant uptake coefficients}

A knowledge of how much of the metals added to soils ends up in crops is the key to calculating standards for pathways 1 and 2 (general population and home gardeners eating crops from soil to which sludge has been applied). Data establishing the relationship between the amount of a contaminant added and its level of uptake by different crops vary widely. In the Part 503 risk assessment, US EPA used the highly non-conservative geometric mean of the data and included data from all soils, including those with high $\mathrm{pH}$. Recalculating 'acceptable' levels using the arithmetic mean or the 90th percentile for uptake coefficients results in a lower standard.

Uptake coefficients, which express the amount of a metal taken up by a plant compared with the amount applied to the soil, are critical to a number of the pathways in the risk assessment. The higher the uptake coefficient, the greater is the fraction of the metal that accumulates in the plant. Uptake coefficients are critical for assessing the pathways that examine people eating sludged crops (pathways 1 and 2) and also the phytotoxicity pathway (pathway 8, Table 2, which assesses negative impact on plant growth resulting from accumulation of some metals, discussed below).

The authors and others (Stern, 1993; Chaney and Ryan, 1994) are concerned that the uptake coefficients used in the US EPA risk assessment are too low, particularly in regard to the northeastern US, where acid soils are common. Also, the uptake coefficients calculated by US EPA include data from lime-stabilized sludges, which have an immediate effect of raising the soil $\mathrm{pH}$, which in turn reduces availability of cadmium and zinc, an effect that cannot be expected to persist in the long term.

Many studies in the field and greenhouse have tried to measure the rate at which a crop takes up a particular metal from the soil. Unfortunately, there is a great deal of variation (the data used by US EPA for cadmium uptake coefficients vary by four orders of magnitude, a factor of 10000 ), depending on many factors including specific variety of crop (not just lettuce 
versus beans, but the particular variety of lettuce), soil characteristics such as caution-exchange capacity, $\mathrm{pH}$, moisture conditions, and many other factors.

In selecting uptake coefficients for the risk assessment, US EPA used the geometric mean of available field data, which results in a much lower number than that obtained if other statistical approaches are used. The uptake coefficient is different for each metal and varies among crops. Because cadmium uptake into crops and subsequent ingestion is a potentially limiting pathway, cadmium is used as an example in the following analysis. While the geometric mean for the uptake coefficient for cadmium in leafy vegetables (a crop type that has a high uptake rate) used by US EPA in the risk assessment is 0.182 , the arithmetic mean of the same data is 0.630 . A probabilistic Monte Carlo analysis of the distribution of uptake coefficient values from the data used by US EPA (excluding soils with a $\mathrm{pH}>6.5$ ) determined that $10 \%$ of the values showed an uptake coefficient of 2.87 or higher, and far more than half the data had levels greater than the level used in the risk assessment (Stern, 1993). For more than $50 \%$ of all soil conditions represented in the risk assessment, the uptake coefficients (and thus the risk posed by cadmium uptake into crops) is underestimated. Because geometric means are biased towards low values, their suitability for use in risk assessment is questionable (Parkhurst, 1998).

For some metals (including lead and mercury), measurements of uptake coefficients appear to be compromised by either analytical limitations or physical contamination of 'control' crops (McBride, 1998a). A number of field plot experiments used in the EPA risk assessment showed low or even negative uptake of these metals. However, the reported concentrations of these contaminants in the control (non-sludged) plants are far higher than levels in farm-grown crops in areas remote from sludged sites. Because uptake coefficients are based on the comparison of concentration in the sludged to the control plots, high levels in the control underestimate uptake. The controls should represent levels in uncontaminated crops, and the elevated levels in the sludge experiment control samples indicate that either the controls were contaminated physically by soil particles carried over from the sludged plots or that there were analytical problems (McBride, 1998a).

\subsubsection{Averages are not applicable to particular site or crop}

Use of averages of means is not a valid approach for some exposure pathways since a particular crop (which may be highly sensitive or accumulate metals more readily) will be grown on a particular site which may have soils that result in high uptake of contaminants by the crop. Similarly, a farmer may be growing a crop that is very sensitive to phytotoxic metals on soils that promote high uptake, leading to low crop yields. The US EPA risk assessment, then, in using the geometric mean for uptake coefficients does not apply conservative estimates and is thus not highly protective. A more protective approach would use data from sensitive crops and soils with high uptake coefficients.

\subsubsection{Cadmium levels under different assumptions}

Different assumptions regarding the appropriate uptake coefficient to use for cadmium in the calculations for pathway 2 (home gardener applying sludge and eating crops) result in very different allowable cadmium levels in sludge (Table 9). For pathway 2, the US EPA risk assessment number is 120 kilograms/hectare $(\mathrm{kg} / \mathrm{ha})$ cumulative cadmium loading. Applying assumptions about depth of tilling into soil, this is equivalent to $120 \mathrm{ppm}$ cadmium in 'EQ' sludges. (Note that the Part 503 standard of $39 \mathrm{~kg} / \mathrm{ha}$ is derived from Pathway 3.) Correcting for the diet recommended by USDA versus the low vegetable diet used in the risk assessment, but using the same geometric mean for uptake coefficient and the same assumptions regarding the acceptable increase in dietary exposure to cadmium, the cadmium limit calculated is $15 \mathrm{~kg} / \mathrm{ha}$ or $15 \mathrm{ppm}$. If instead the arithmetic mean of the data is used for the uptake coefficient, $5 \mathrm{~kg} / \mathrm{ha}$ or ppm is calculated. For this pathway, application of the values derived from a Monte Carlo analysis show that a maximum cadmium contaminant level of 1.5 
$\mathrm{kg} / \mathrm{ha}$ or $\mathrm{ppm}$ is calculated to be protective of persons gardening in $90 \%$ of the slightly to strongly acidic soils included in the data base and eating the USDA recommended diet. As seen in Table 5, other countries have adopted cadmium standards approaching this low limit. Although currently many NYS sludges could not meet this limit, with aggressive pollution prevention this number could be achieved, as seen by the fact that many European sludges are able to meet their more stringent limits.

Table 9 Cadmium standard calculated using different assumptions regarding diet and uptake coefficient (UC) (values are in kg/ha).

\begin{tabular}{cl}
\hline $\begin{array}{l}\text { Acceptable } \\
\text { cadmium } \\
\text { cumulative limit }\end{array}$ & Basis \\
\hline 120 & $\begin{array}{l}\text { EPA calculation based on geometric mean UC and } \\
\text { average late 1970s diet } \\
\text { Concentration based on geometric mean UC and } \\
\text { USDA recommended diet } \\
\text { Concentration based on arithmetic mean UC and } \\
\text { USDA recommended diet } \\
\text { Concentration based on Monte Carlo 90th percentile } \\
\text { UC and USDA recommended diet } \\
\text { EPA cumulative limit based on child ingestion } \\
\text { pathway }\end{array}$ \\
\hline
\end{tabular}

\subsection{RfD for arsenic of $0.0008 \mathrm{mg} / \mathrm{kg} /$ day vs. 0.0003 or less}

The reference dose (RfD) of a toxic chemical is the daily exposure over a lifetime likely to be without 'appreciable' risk. It is expressed as the amount that can enter the body per kilogram of body weight per day. For arsenic, there is some uncertainty regarding the recommended maximum level. US EPA believes it to fall within the range of $0.0001-0.0008$ $\mathrm{mg} / \mathrm{kg} /$ day. US EPA selected the least conservative number $(0.0008 \mathrm{mg} / \mathrm{kg} /$ day $)$ in the Part 503 risk assessment, despite the fact the RfD used by US EPA in other programmes is $0.0003 \mathrm{mg} / \mathrm{kg} /$ day (US EPA, 1992, pp. 5-107). A recalculation using the same assumptions as US EPA in the Part 503 risk assessment except for the use of an RfD of $0.0003 \mathrm{mg} / \mathrm{kg} / \mathrm{day}$ for arsenic, produces an acceptable limit of $1 \mathrm{ppm}$ of arsenic in sludge products based on pathway 3 , child ingestion of soil (TNRCC, 1996).

\subsection{Many pollutants not regulated or monitored}

\subsubsection{Pollutants present in less than $10 \%$ of sludges not considered}

A key issue is the very limited number of contaminants that are regulated under Part 503. In developing the rules, US EPA used a national perspective, not considering contaminants 'infrequently' found in sludges. In the first round of regulation development that led to the Part 503 rules, there was not a formal definition of the frequency of detection necessary for consideration, nor was there a consistent database of sludge quality from treatment plants in the US. That was one reason why US EPA sponsored the National Sewage Sludge Survey in 1988 (US EPA, 1990). For Round 2 of regulation development, contaminants found in $10 \%$ or fewer of sludges (determined by the 1988 survey) were not considered 
significant enough to regulate. However, in up to one out of ten sludges, these contaminants may be present and possibly at levels of concern.

Although on a national scale the risks posed by such contaminants may be low, the particular sludge that a grower or home gardener may use might in fact have significant levels of some unregulated contaminants without their having any way of knowing because no monitoring is required for these contaminants. Consider, for example, a hypothetical small city where an industry infrequently discharges a highly toxic contaminant not included in the Part 503 rules. A survey of sludges from 24 central NYS communities and another of 30 sludges from around the US documented just such a concern, finding elevated levels of various exotic contaminants in sludges from communities in which a particular industry was located (Mumma et al., 1983; Mumma et al., 1984).

\subsubsection{Pollutants with insufficient data}

Another rationale for not setting standards or requiring monitoring is the inability to adequately assess risks due to a lack of data with which to complete the risk assessment. Lack of adequate data is a serious limitation to the usefulness of risk assessment, but ignorance is not a solution to uncertainty. Currently, US EPA rules only require monitoring for regulated contaminants. Testing sludges for a wider range of priority pollutants and for dioxins and furans would not include all of the thousands of chemicals that might be present, but would be a step towards knowing what is being spread on land. One issue with wider testing is that the significance of detecting contaminants for which there are no regulatory limits is unclear. The data on many chemicals are not adequate to assess their impacts. Finding chemicals through wider testing, however, can at least alert us and research can be undertaken to assess their effects.

In their Round 2 evaluation of additional pollutants in sewage sludges, US EPA identified an additional 12 inorganic and organic chemicals beyond those regulated in Part 503 that are potentially harmful by one or more exposure pathways. The arguments ultimately used to exclude all but two of these (coplanar PCBs and dioxins/ dibenzofurans) from further consideration can be called into question; most are based on a lack of data.

If the leachability of beryllium and barium is assumed to be as high as has been measured in acid sandy soils, both of these elements would have been subject to regulation to limit groundwater contamination (US EPA, 1996b). For barium, US EPA in the risk assessment used the lowest rather than the highest or median measured leachability for acid sandy soils, based on a single experiment. For beryllium, the median value of leachability was used.

US EPA excluded boron and fluoride from regulation despite both elements having critical pathways (pathway 6 for boron, pathways 6 and 10 for fluoride [Table 4]), arguing that the experiments from which this initial assessment of potential impact was derived did not measure transfer into biota from boron and fluoride in soils amended specifically with sludges. Since no information was available on uptake of either element from sludge into crops, US EPA concluded that the pathways could not be evaluated with existing information, and that boron and fluoride should not be regulated. However, both of these elements occur as anions and may not be strongly adsorbed in the sludge matrix. The initial solubility of boron in some sludges and composts is especially high, such that boron phytotoxicity in crops grown on soils recently amended with sludges has been observed (Chaney and Ryan, 1994). It is questionable whether it is reasonable to assume little transfer to animals and soil biota, given the absence of data. The current position of US EPA that further research is not needed on land application of sludges is inconsistent with the arguments of insufficient data used to eliminate many contaminants from consideration for regulation. 


\subsubsection{Synthetic organic chemicals}

No organic contaminants are currently regulated under Part 503. The US EPA eliminated from consideration any organic contaminant that met any of the following three criteria. The criteria used were: (1) the pollutant has been banned for use in the US or it is not being manufactured for US use; or (2) it has been detected in $5 \%$ or fewer of the sludges tested in the National Sewage Sludge Survey; or (3) the 1-in-10 000 cancer risk limit was less than the concentration found in $99 \%$ of the sludges tested. Thus, even persistent synthetic organic chemicals found to be present in more than $5 \%$ of sludges were eliminated from regulation if they were no longer being manufactured (US EPA, 1992, 1995).

PCBs are an example of a class of organic contaminants generally found at low levels, but at high levels in some sludges. The risk assessment performed by US EPA shows that $4.6 \mathrm{ppm}$ would be the limit for acceptable risk using a 1-in10000 cancer risk. In contrast, the rules in Texas set a $1 \mathrm{ppm}$ standard for residential use, and the Dutch clean-up intervention value is $1 \mathrm{ppm}$ in soil (Tables 5 and 6) (Texas, 1996; van den Berg, 1994). A reassessment of pathway 5 by Chaney et al. arrived at a limit of $2.23 \mathrm{ppm}$ for PCBs based on the pathway of a farm family consuming meat (Chaney et al., 1997), but for a number of reasons the US EPA rules were stated to be adequately protective (Chaney et al., 1996).

PCBs are not regulated under Part 503 because they are no longer being manufactured in the US. Many chlorinated synthetic organic chemicals, such as PCBs and dioxins, are persistent, slow to degrade, and they bioaccumulate. More than $50 \%$ of dioxins and furans were still present in soil 20 years after sludge application (McLachlan et al., 1996).

Most sludges contain low levels, but some individual sludges contain significant amounts. Monitoring of persistent synthetic organic chemicals, such as PCBs, is not required under US EPA rules but has been recommended, even by researchers who believe the toxicity risk from these chemicals resulting from land application of sludges is very low (Chaney et al., 1996). Again, this is a case of the 503 regulations dealing with 'average' rather than specific conditions. While it is stated that 'PCB concentrations will limit use of biosolids from only a few of the 14000 POTWs [publicly owned treatment works] in the US' (Chaney et al., 1996), a sludge user would have no way of knowing without testing, if the sludge or sludge product they are applying is one of those few. The particular pathway of concern is ingesting sludge. In addition, since PCBs (and other persistent, fat-soluble toxic organics) bioaccumulate in animal fats, ingestion of sludges containing such organics by cattle could be a concern regarding milk and meat quality.

Dioxins and furans are a series of related compounds, some level of which were found in all sludges tested in the 1988 National Sewage Sludge survey conducted by US EPA (US EPA, 1996a, c). Since the toxicity of the different particular types (known as congeners) varies widely, EPA and others have defined a toxic equivalency factor (TEQ), which is a calculated number varying from 1 for $2,3,7,8-\mathrm{TCDD}$, the most toxic, to 0.001 for other less toxic types. To calculate the total risk posed by dioxins and furans in a sludge, the concentration of a particular type of toxin or furan is multiplied by the toxicity factor for that particular type and then summed for all the dioxins and furans that are present, to arrive at a total TEQ. Levels in sludges vary widely, with a mean value of 10-20 ng/kg TEQ, but some sludges have a TEQ of over $100 \mathrm{ng} / \mathrm{kg}$. Although no regulations are in place regarding the land application of materials containing dioxins, an agreement between the paper companies and US EPA regarding land application of paper mill sludges established $10 \mathrm{ng} / \mathrm{kg}$ TEQ as the limit for unregulated spreading, and paper sludges containing over $50 \mathrm{ng} / \mathrm{kg}$ are not to be land applied. For levels between 10 and $50 \mathrm{ng} / \mathrm{kg}$ TEQ, site-specific evaluation would govern use. There are thus a number of sewage sludges that would not be spread under these criteria. It has been suggested that dioxins may be a limiting factor in the application of sludges in Ontario where there is a risk-based soil clean-up level for dioxins of $10 \mathrm{ng} / \mathrm{kg}$ TEQ (Campbell and Webber, 1997; Webber and Nichols, 1995). Dioxins and furans and co-planar PCBs are the only additional pollutants that US EPA is proposing to address in Round 2, which is expected to take several years. In the meantime, federal rules do not require testing for these contaminants. 
A number of organic contaminants that are components of detergents are found in relatively high levels in sludges including linear alkylbenzene sulfonates (LAS), nonylphenol (NP), nonylphenol ethoxylates (NPE) and di-(2ethylhexyl)phthalate (DEHP) (Giger, 1997). These vary in toxicity and degradability in the soil environment, but some are suspect regarding hormonal mimicking actions. To date, these contaminants have not been assessed by US EPA in regard to land application of sludges. Further research on their effects on humans and animals is needed (Krogmann et al., 1997). Switzerland has banned the use of nonylphenol, and a number of other countries have set standards for these constituents, as well as for total polycyclic aromatic hydrocarbons (PAHs), dioxins and for some measurement of total chlorinated organics. In Sweden, recommended limits for a number of organic contaminants were established in negotiations with the agricultural community. Maximum concentrations of $50 \mathrm{mg} / \mathrm{kg}$ for nonylphenol, $5 \mathrm{mg} / \mathrm{kg}$ for toluene, $3 \mathrm{mg} / \mathrm{kg}$ for PAHs and 0.42 $\mathrm{mg} / \mathrm{kg}$ for PCBs have been established (Matthews, 1996).

\subsubsection{Radioactivity}

Radioactivity is not addressed in Part 503. Little is known about the extent to which sewage sludges are contaminated with radioactivity and monitoring is not required. Although the average sludge may contain little radioactivity, individual sludges receiving waste water from various types of facility may reconcentrate radioactivity in sludges (US GAO, 1994). Further investigation is needed, particularly where potential sources that discharge to sewage treatment plants include nuclear facilities, hospitals and other medical facilities, or leachates from superfund sites with radioactive contaminants. US governmental agencies are currently conducting a survey of radionuclides in sludges.

\subsection{Ground and surface water calculations assume large dilution/attenuation}

\subsubsection{Leachate diluted/attenuated before reaching well}

Although the US EPA risk assessment for the groundwater pathway (pathway 14, Table 3) states that the objective is to protect a shallow well immediately downgradient of a sludge field, the calculation assumes a large reduction of peak metal concentrations (through dilution and/or attenuation) by the time that leachate reaches a well (e.g., the reduction factor for arsenic is 244). Depending on numerous characteristics of the site and contaminant, a well in the vicinity of sludged fields may not receive the benefit of that great a reduction.

The generally held belief that metals in sludges cannot readily leach has been called into question by recent data (Camobreco et al., 1996; Richards et al., 1997). Working with undisturbed soil columns rather than the repacked soil columns used in previous experiments, the potential for leaching of metals has been demonstrated. In undisturbed soils, channels created by worms and roots and other processes ('macropores') provide for rapid downward water movement that can limit the adsorption or chemical interactions between the percolate and the soil. Transport appears to be governed by this fast and far-reaching preferential flow and by the relatively non-reactive forms of some of the metals, i.e., as soluble and/or colloidal complexes. Most sludge research to date has overlooked this phenomenon. High $\mathrm{pH}$ (such as in alkalinestabilized sludge products) can actually increase leaching, since the solubility of some organically complexed metals is high under such conditions. Examination of field research data collected over the years by many researchers shows that typically up to half of some metals applied in sludges appear to be 'missing' from the soil and may have leached. Transport of a range of metals in percolating water has been directly observed at a field site where sludge was applied more than a decade earlier (McBride et al., 1997).

Concentrations of $\mathrm{Cd}, \mathrm{Ni}$ and $\mathrm{Zn}$ exceeded US drinking water standards in leachate collected from lysimeters 
immediately below soils receiving sludge 20 years after a large amount of sludge had been applied to agricultural soils (Richards et al., 1997). Calculations of impacts on groundwater indicate the potential for violation of drinking water standards in the vicinity of sludge application sites (Richards, 1997). The US EPA risk assessment assumptions may not be sufficiently protective of wells near sludge application sites. Further investigation is needed to ascertain if there is a significant concern for both metals and pathogens in groundwater, as pathogens could migrate by preferential flow as well.

\subsubsection{Only $0.24 \%$ of the model watershed receives sludge}

There is concern for the quality of surface water in the vicinity of sludge application sites. There is potential for contaminants including metals and pathogens to be present in surface runoff and in shallow percolating water that reaches tile drains which are common beneath fields in the northeast. The US EPA risk assessment used unrealistic assumptions regarding dilution of contaminants.

A key parameter in the surface water exposure pathway is the amount of the watershed that has received sludge. The Part 503 risk assessment assumes that only 1074 ha out of a 440300 ha watershed receives sludge. This may be applicable to a very large watercourse, but in a local area a far greater proportion of a smaller stream's watershed may have received sludge. Figure 1 shows the size of such a drainage basin (in the upper Hudson River in NYS) and depicts the tiny fraction assumed to receive sludge applications. US EPA's choice is thus not protective of the smaller streams in agricultural areas where sludge is applied. For example, a change in the percentage of watershed area receiving sludge to assume a 100 acre farm receiving sludge in a 1000 acre watershed would lower calculated limits for PCBs by more than 95\% compared with the US EPA assumptions (Cleland, 1995). 


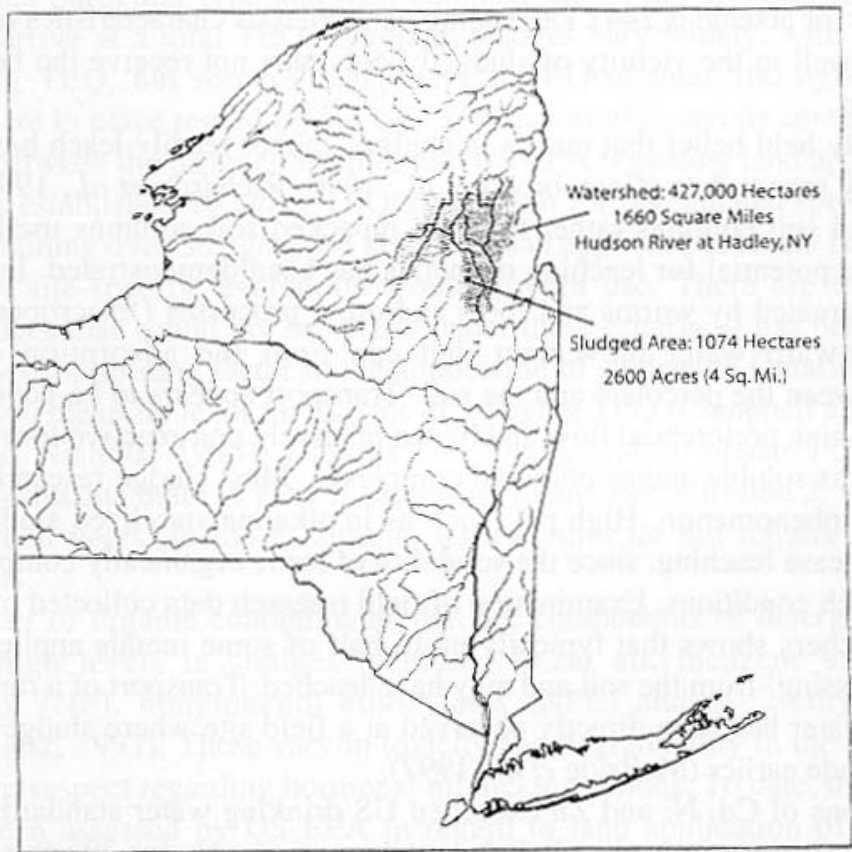

Figure 1 Map of New York showing example of size of drainage basin and proportion receiving sludges under Part 503 risk assessment assumptions. 
Recent laboratory and greenhouse research has shown that some metals present in sludges $(\mathrm{Cu}, \mathrm{Mo}, \mathrm{Ni})$ are relatively soluble in the very alkaline product created by the mixing of sludge with cement kiln or fly ash and lime. Much smaller proportions of a number of other metals (Ag, Cd, Hg, Pb, Zn) were immediately water-soluble (McBride, 1998b; Richards et al., 1997). This solubility, probably the result of complexation with dissolved organic substances, suggests the potential for the movement of the soluble metals from land-applied alkaline sludge products into surface waters and shallow groundwater under some conditions. Further work is necessary to investigate field conditions. The sensitivity of aquatic organisms to dissolved copper suggests that a large dilution factor would be required to prevent toxicity in surface waters receiving run-off from areas where such sludge products have been applied to the surface (McBride, 1998b).

\subsection{Not protective of agricultural productivity}

\subsubsection{Phytotoxicity and crop yield reduction}

Appropriate use of sludges on agricultural lands has positive effects on plant growth through the addition of nutrients and organic matter. Excessive accumulation of certain metals, such as copper, zinc and nickel, reduces crop yields. There is thus a need to assess not only short-term benefits, but long-term risks of yield reduction due to accumulation of contaminants over time. This pathway (Pathway 8, Table 3) was evaluated by US EPA in the risk assessment and has also been considered by agronomists at the land grant universities in the northeast (Pennsylvania State University, 1985). The cumulative limits for copper, nickel and zinc in the Part 503 regulations are approximately ten times those recommended by the northeast soil scientists.

Acceptable cumulative levels of nickel and zinc depend on calculations of the uptake coefficients and of the yield reductions that are associated with the concentration of metals in the crop tissue resulting from uptake. As discussed above, the US EPA risk assessment used values for uptake coefficients that are not conservative. Not all elements exhibiting phytotoxic impacts can be assessed with this plant uptake model. For copper, for example, roots are affected by toxicity before tissue levels in the crop are elevated significantly. Assessing the risk of yield reduction based on uptake coefficients and tissue levels is not appropriate for such elements.

The yield reductions calculated in the EPA risk assessment are higher than most growers would find acceptable. For some growers, any reduction would be unacceptable. In one method, US EPA calculated the cumulative load of zinc allowed under Part 503 based on the probability that it could result in a 50\% yield reduction. Although the US EPA calculations assert a low probability of such a reduction, a standard based on such a calculation is not useful since such a high yield reduction is clearly unacceptable. Recalculation indicates that with a loading of approximately one-tenth of the zinc standard in Part 503, yield reductions of $10 \%$ are likely in $10 \%$ of the soil-crop combinations in the US EPA database (Bouldin, 1997).

Protecting agricultural productivity, especially in the northeast USA where soils are acid and sensitive crops such as beans or alfalfa are raised (Table 10), makes it prudent to restrict cumulative additions of phytotoxic metals.

Based in part on values derived by a group of northeastern US soil scientists, who recommended a sliding scale for phytotoxic metal loading limits according to soil texture (Pennsylvania State University, 1985) the recommendations of this paper (Table 11) for copper, zinc and nickel are close to one-tenth of the Part 503 cumulative load standards. The 
recommendations in this paper also take into account soil metal levels known to cause toxicity to crops in specific field experiments, as well as a reassessment of the US EPA database on phytotoxicity applying more conservative assumptions.

\subsubsection{Soil microorganisms}

Experiments at a number of long-term sludge-treated field sites in the UK, Germany and Sweden, where metals had accumulated and persisted for decades, have shown that microbial functions in soils can be adversely affected at metal concentrations that are not necessarily toxic to crops. Rhizobium populations in the soil can be reduced when the zinc, copper, nickel and cadmium concentrations reach 130-200, 27-48, 11-15 and 0.8-1.0 mg/kg (ppm), respectively, in the soil (McGrath et al., 1995). Other microorganisms, such as free-living nitrogen-fixing heterotrophic bacteria and phototrophic cyanobacteria, are sensitive to heavy metals at these or even lower levels. The soil microbial biomass is reduced at zinc, copper, nickel and cadmium concentrations ranges of 180-857, 70-384, 22-35 and 0.7-6.0 mg/kg, respectively. Generally, higher soil $\mathrm{pH}$ and increased content of clay and organic matter in the soil mitigate toxicity, shifting the limiting concentrations toward the higher end of these ranges. Based on the negative effects observed on soil microbes, the advised limit in the UK for zinc in soils was adjusted downward from 300 to $200 \mathrm{mg} / \mathrm{kg}$ (UK Dept. of the Environment, 1995). The risk assessment for Part 503 does not set limits based on soil microorganisms (McGrath et al., 1994; US EPA, 1992).

Table 10 Relative sensitivity of crops to sludge-applied copper, nickel and zinc. ${ }^{a}$

\begin{tabular}{|c|c|c|c|}
\hline Very sensitive & Sensitive & Tolerant & Very tolerant \\
\hline Chard & Mustard & Cauliflower & Corn \\
\hline Lettuce & Kale & Cucumber & Sudangrass \\
\hline Beet & Spinach & Zucchini squash & Smooth bromegrass \\
\hline Carrot & Broccoli & Oat & \\
\hline Turnip & Radish & Orchardgrass & \\
\hline Peanut & Tomato & Switchgrass & \\
\hline Clovers & Birdsfoot trefoil & Kentucky Bluegrass & \\
\hline Crownvetch & Soybean & Fescues & \\
\hline Alfalfa ${ }^{b}$ & Snapbean & & \\
\hline \multirow[t]{3}{*}{ Sunflower ${ }^{c}$} & Timothy & & \\
\hline & Bentgrasses & & \\
\hline & Ryegrass & & \\
\hline
\end{tabular}

$a$ Adapted from Chaney and Hundermann in US EPA, 1992.

$b$ Hydroponic study (Ibekwe et al., 1996).

c Metal salts added to soil (Gorlach and Gambers, 1992).

\subsubsection{Animal health}

Animals that graze on land to which sludge has been applied to the surface will ingest sludge along with the plants and 
some soil. Grazing cattle ingest from $1-18 \%$ of their dry matter intake as soil and sheep may ingest as much as $30 \%$ depending upon management and the seasonal supply of grass (Thornton and Abrahams, 1983). The US EPA risk assessment assumes a soil ingestion of $1.5 \%$ of diet. This is a non-conservative estimate based on use of best management practices. Incorporation of sludge into the soil can help prevent impacts to animal health, but the practice is generally to apply sludge to the surface in pasture land applications. US EPA regulations do not restrict grazing on lands to which Class A sludges have been applied and allow grazing 30 days after application of Class B sludges. The adequacy of this onemonth period for protection against pathogen transmission has been questioned, with an 18-month waiting period suggested (National Research Council, 1996). Denmark and Sweden do not allow application of sludges of any kind to lands used for grazing (Matthews, 1996). 
Table 11 Recommended maximum concentrations of contamination in soils (values are in ppm).

\begin{tabular}{lccc}
\hline Contaminant & $\begin{array}{c}\text { Typical NYS sludge } \\
\text { conc. }\end{array}$ & Typical NYS ag.soil & Rec'd soil max conc. \\
\hline Arsenic & $3-10$ & $<9$ & $1-10^{2}$ \\
Cadmium & $2-15$ & 0.2 & $2^{3}$ \\
Chromium & $50-500$ & 52 & -4 \\
Copper & $300-1500$ & 20 & $40-100^{5}$ \\
Lead & $100-300$ & 15 & -6 \\
Mercury & $1-10$ & 0.1 & $1^{7}$ \\
Molybdenum & $5-50$ & 1.0 & $4^{8}$ \\
Nickel & $10-150$ & 16 & $25-50^{9}$ \\
Selenium & $2-6$ & 0.4 & $5^{10}$ \\
Zinc & $500-2500$ & 60 & $75-200^{11}$ \\
PCBs & $<5$ & & $1^{12}$ \\
\hline
\end{tabular}

1 Based on a survey of NYS sludges (NYS DEC, 1994).

2 Risk assessment based on child ingestion and $0.0003 \mathrm{RfD}$ suggests $1 \mathrm{ppm}$ concentration limit for sludges used at home (Texas Natural Resources Commission, 1996). Background soil often exceeds 1 ppm so a range is suggested as potentially acceptable.

3 A limit of 2 ppm is recommended due to crop uptake concerns.

4 The chemical form of chromium is of critical importance. Chromium(III) is of little concern because it forms relatively insoluble compounds, whereas chromium(VI) is highly toxic and soluble. Little information is available on the ionic status of chromium in sludged soils and the potential for chromium oxidation in sludged soils.

5 Concentration limit to prevent phytotoxicity based on the northeast guidelines (Pennsylvania State, 1985). 40 ppm for sandy soils, 60 ppm for fine sandy loam to silt loam, 100 ppm for silt to clay soils.

6 The lowest attainable levels are desirable since negative human impacts continue to be discovered at increasingly low levels. Child ingestion is the primary concern.

7 The lowest attainable levels are desirable. Ecotoxicological and groundwater impacts are likely to be the determining factor.

8 Excessive molybdenum can result in molybdenum toxicity (induced copper deficiency) in ruminants. A minimum dietary $\mathrm{Cu}: \mathrm{Mo}$ ratio of 2 is advised. Testing forages for molybdenum and copper periodically and preventing ruminants from grazing on land to which sludge has been applied and not incorporated into the soil is recommended.

9 Concentration limit to prevent phytotoxicity based on the northeast guidelines (Pennsylvania State, 1985). 25 ppm for sandy soil, 35 ppm for fine sandy loam to silt loam, $50 \mathrm{ppm}$ for silt to clay soils.

10 This may be high. Test forages periodically for selenium to assure that concentration does not exceed that considered toxic to animals.

11 Concentration limit to prevent phytotoxicity based on the northeast guidelines (Pennsylvania State, 1985). 75 ppm for sandy soils, 130 ppm for fine sandy loam to silt loam, $200 \mathrm{ppm}$ for silt to clay soils. Higher concentrations can be tolerated in calcareous soils.

12 Based on EPA recommended soil levels (US EPA, 1990). 
Molybdenum (Mo) and selenium (Se) can be readily taken up by plants (high uptake coefficients) at concentration levels toxic to foraging animals. There is a narrow range between necessary nutrient levels and toxicity for these elements, and naturally occurring levels of these metals are highly variable within US soils. Molybdenum toxicity in ruminant animals (Mo-induced $\mathrm{Cu}$ deficiency) is associated with forages containing $10-20 \mathrm{mg} / \mathrm{kg}$ of Mo (or more) with relatively normal concentrations $(4-10 \mathrm{mg} / \mathrm{kg}$ ) of $\mathrm{Cu}$ in the forage (Kubota and Allaway, 1972). Molybdenum availability in soils is enhanced by alkaline soil conditions, high phosphate fertilization, and high organic matter content (Fleming, 1980). Under such conditions, $2-3 \mathrm{mg} / \mathrm{kg}$ of total Mo in soil has produced forages with toxic concentrations for ruminants. Selenium toxicity in ruminants occurs if forages contain $5-10 \mathrm{mg} \mathrm{Se} / \mathrm{kg}$ (Jacobs, 1989). Calcareous or alkaline soils with as little as $0.5-2.0 \mathrm{mg} / \mathrm{kg}$ of total Se can produce forages with Se at toxic levels (Purves, 1985). Studies of uptake into red clover (McBride et al., in preparation) and forage grass (Nguyen and O'Connor, 1997) suggest that uptake is sufficiently high to call for limiting molybdenum additions to soils where forage is grown.

Most of the concerns about metal contamination following land application are related to long-term soil loading and are thus unlikely to result in impacts in the short term. In contrast, the potential for molybdenum toxicity can be an immediate concern. Application of sludges could pose some risk because sludge Mo and Se are relatively soluble in sludges and are present at higher concentrations than in most soils. The high $\mathrm{pH}$ of alkaline-stabilized sludge products are conducive both to water solubility and to plant absorption of these elements. As with other calculations in the risk assessment on which the Part 503 rules are based, the geometric mean of uptake coefficients from the very few studies of Mo uptake were used. This resulted in a cumulative limit of $18 \mathrm{~kg}$ of Mo per hectare, which was subsequently deleted from the rules, so that presently there is only a ceiling concentration limit of $75 \mathrm{ppm}$ for Mo. The assumption that increased copper uptake resulting from sludge application would be adequate to offset the Mo taken up by crops is not supported by research data (McBride et al., in preparation; Webber et al., 1983). Uptake of Mo into legumes is relatively high, particularly from alkaline sludge products commonly used in NYS. Since a dairy herd may predominantly be fed on forage such as alfalfa (a legume) from a particular farm, protection of the health of ruminant livestock whose diet is forage grown on sludge-amended soils suggests that limiting soil concentrations of Mo to approximately $2 \mathrm{mg} / \mathrm{kg}$, and limiting loading rates to $1-2 \mathrm{~kg}$ of Mo per hectare may be necessary (McBride, 1998c). In the UK, a maximum soil concentration of $4 \mathrm{mg} / \mathrm{kg}$ is advised.

Iron, which can be high in sludges, can also cause toxicity in grazing animals by direct ingestion of sludge retained on forage. It is not one of the elements for which sludges must be tested or for which there are standards. Ingestion of soil is also an important and possibly even dominant pathway for lead and arsenic transfer into grazing animals (Thornton and Abrahams, 1983).

Animal health is sensitive to the ratios of different metals in their diets, so analysis of the various metals in both the sludge is well as other components of the animal diet needs to be conducted for the particular type of animal being raised.

\subsection{Inadequate assessment of pathogen risks}

Sludges contain a high concentration of pathogenic viruses, bacteria and parasites. In fact, most microbes that are present in raw sewage are concentrated in sludge. The levels and types are dependent in part on the health of the population contributing to the sewage plant and will vary over time as the health of the population varies. The type of sludge treatment also affects the viability of pathogens. High treatment temperatures $\left(>56^{\circ} \mathrm{C}\right)$ are relatively effective in killing pathogens.

Prior to land application, sludges must be treated to reduce pathogen levels. Class B sludges still contain significant levels of pathogens (Straub et al., 1993). Class A sludges and sludge products have received higher levels of treatment (generally hotter for longer). If not killed, the small size of viruses and other pathogens may potentially permit them to leach 
to groundwater (Powelson et al., 1991). This may be the most likely route of significant human exposure to pathogens from land applied Class B sludges (Straub et al., 1993). There is a need for field data regarding the movement of pathogens, particularly where groundwater is found at shallow depths and soils are conducive to preferential flow. Few viruses have been studied in regard to sludges and unfortunately unlike viruses behave differently (Dubovi, 1997). No monitoring is currently required for viruses in sludge or sludge products.

Bacteria, unlike either viruses or parasites, can actually increase in numbers during treatment under certain conditions. Regrowth in composts that were not fully stabilized has been documented (Soares et al., 1995). Thus a compost could have met processing requirements and standards for E. coli or Salmonella (US EPA requires testing for one or the other for Class A), but could subsequently have significant bacterial levels if regrowth occurs after testing.

Parasites such as Helminth ova are relatively resistant to inactivation when present as cysts. In Class B sludges they could be present in significant numbers and they have been documented to survive for many years in soils (Bowman, 1997). Little is known about the presence and viability of Cryptosporidium and Giardia in sludges. High levels of cysts of Giardia have been detected in sludges, but they may be inactivated (non-infective). More research is needed to assess the risks posed by these protozoa (Straub et al., 1993).

Generally cooler, wetter conditions such as those found in the northeastern US favour survival of pathogens in the soil.

\subsection{Ecological impacts inadequately assessed}

The US EPA risk assessment addressed only the impact of copper on earthworms, and of cadmium, lead and PCBs on shrews using only field data from agricultural sites.

Recognizing the limitations of this analysis, an EPA-funded study has been carried out at Oak Ridge National Laboratory to assess the current state of knowledge on ecological impacts of sludge application. This study, which examined impacts to plants and animals, has not yet been released. Preliminary results indicate that for some contaminants, ecological risk may become the most limiting pathway. The standards for soil quality derived from the Dutch risk assessment found ecotoxicologic impacts to be the most sensitive measures requiring the lowest standards (van den Berg et al., 1993; Crommentuijn et al., 1994; Swartjes, 1997). The paucity of ecological effects data used in developing Part 503 rules is likely an important reason why these rules are far less restrictive (McGrath et al., 1994). The Part 503 rules will need to be reassessed when the results of the Oak Ridge study are available to determine what changes in contaminant levels may be needed to protect ecological systems.

Efforts to curb emissions of mercury are underway in New York state and elsewhere, owing to its toxicity and propensity to bioaccumulate. Recent research has demonstrated that some of the mercury in land-applied sludges volatilizes, and that the concentration of mercury in air over sludge sites contains 10 to 100 times the background concentration (Carpi and Lindberg, 1997). The EPA risk assessment assumes that no mercury is volatilized from land application. A review of the risk assessment in the light of the new findings suggests that, for most pathways, there is not a substantial concern, but that the potential to impact local waterbodies through redeposition of methylmercury may be signficant and warrants further analysis (Carpi, 1997). Worldwide sludge land application is estimated to emit to the air about one-eighth of the amount of mercury discharged by power plants or by municipal waste incinerators (Carpi and Lindberg, 1997).

\subsection{Inadequate enforcement and oversight}

Enforcement (or the lack thereof) of rules and practices, such as use of agricultural best management practices, is a significant issue. This concern is magnified as both federal and state budget cuts force a reduction in environmental staff. 
US EPA has said that they view the 503 regulations as largely 'self-implementing'. Under the Part 503 regulations, sludge producers are required to follow processing procedures and perform monitoring. Periodic reporting is required, but no permits are issued for land application (note that NYS currently requires site-specific permits for Class B applications) and no record-keeping of application is required for Class A 'EQ' sludges. Such a system gives neighbours of land application sites and others little confidence that rules will be followed. Without permits or records, there is no way for concerned parties to know even whether or not sludge products have been applied. It may also prove difficult for anyone to keep track of the cumulative load of metals applied from non 'EQ' sludges. Interestingly, even in Ontario where records were required, researchers found that they could not locate sludge application records because sludge haulers did not turn over records when contracts were transferred (OMAFRA, 1995).

Adherence to best management practices, some of which are specified in federal and state rules, is of critical importance in preventing negative impacts from sludge application. Further management practices may be recommended by agricultural advisors (e.g. Cornell Cooperative Extension, 1997; Cornell Waste Management Institute, 1997a). Without oversight there is concern that even required practices, such as application at no higher than agronomic rates necessary to meet crop nutrient requirements or maintenance of setback distances from watercourses, may not be followed, leading to water pollution.

\subsection{No labelling of sludges or sludge products}

For sludge and sludge products that meet the EQ standards set in Part 503, no labels or information for users are required. Thus information on the quality of the product is not readily available to potential users. Labelling is needed that includes analytical information about the concentrations of contaminants and nutrients in the material. Growers and their advisors need the information to make appropriate decisions about nutrient management. Additionally, if those electing to use a sludge or sludge product want to select the cleanest possible material or to follow more stringent recommendations (such as those in Table 11), they require information on contaminant concentrations.

\section{Conclusions}

US national standards for the land application of sewage sludges are markedly less stringent than those of many other countries. The standards were developed through an extensive risk assessment, but data gaps and non-protective policy choices result in regulations that are not adequately protective of human health and the environment.

The exposure pathways and significance of impacts for home use, agricultural use and other applications, such as to golf course turf and roadside vegetation, are significantly different. For home use, more stringent standards are appropriate, reflecting the greater likelihood of child ingestion of sludge and the potential for less careful management. For use on agricultural lands, phytotoxicity concerns are of greater significance. For many other uses, these pathways are of less import, which might result in less stringent standards.

The application of sewage sludges to agricultural lands and home grounds should be based on acceptable resultant contaminant concentrations in the receiving soil. Where a single set of standards is applied regardless of end use, the limits should reflect the most limiting pathway. Table 11 suggests maximum soil concentrations appropriate for soils in the northeastern US. The numbers are for recommended maximum soil concentrations, and reaching these levels will depend on initial soil concentrations, the concentration of the contaminant in the sludge, the total loading of sludge applied and any losses (e.g. through leaching). Limiting application to these maximum levels will also help to prevent excessive 
contamination with currently unregulated contaminants by limiting the amount of sludge that could be applied over time. Sludges with contaminant concentrations at or below the levels listed for maximum soil concentrations in Table 11 could be applied in unlimited cumulative amounts without exceeding the recommended soil concentrations for contaminants. (Application at appropriate annual rates to ensure that nutrient levels are not exceeded is still required.) For sludges exceeding the Table 11 recommended maximum concentrations, calculations should be made to determine the cumulative amount of sludge that could be applied without exceeding the recommended soil concentration.

In addition to testing of receiving soils, monitoring for a number of currently unregulated contaminants should be required, and test results should be provided to potential users to enable them to compare different sludges. Tests should include synthetic organic chemicals (including dioxins and furans), antimony, beryllium, boron, chromium, and silver. If animals will be grazing or if forage is grown, copper, fluoride, iron, molybdenum and selenium should be monitored and dietary metal ratios considered.

Further research is needed on nitrogen release rates, the movement of metals and pathogens to ground and surface water, the presence and impact of synthetic organic contaminants and of contaminants eliminated from US EPA Round 2 consideration due to inadequate data, and ecological impacts (including soil organisms). Additional standards should be developed to address the research findings.

Policies should be designed to support pollution prevention to promote continued improvement in sludge quality. This includes establishing outreach and technical assistance programmes, as well as regulations that minimize the use of undesirable contaminants, especially those which are persistent in the environment. 'Clean sludge' standards should be set at levels low enough to motivate minimization of pollutant concentrations.

\section{References}

Bouldin, D.R. (1997) 'Why guidelines for beneficial use of sludges in agriculture are different and estimates of alternatives', Soil Sciences Society of North Carolina Proceedings.

Bowman, D. (1997) 'Parasites in sewage sludges', presentation to Cornell Sludge Working Group, 8 May.1997.

Camobreco, V.J., Richards, V.K., Steenhius, T.S., Peverly, J.H. and McBride, M.B. (1996) 'Movement of heavy metals through undisturbed and homogenized soil columns', Soil Sciences, Vol. 161, pp. 740-750.

Campbell, H.W. and Webber, M.D. (1997) 'Biosolids management in Canada: current practice and future trends', paper presented at the Specialty Conference on Management and Fate of Toxic Organics in Sludge Applied to Land, Copenhagen, Denmark, April 30-May 2, 1997.

Carpi, A. (1997) 'The surface/atmosphere exchange of elemental and methylmercury over background and municipal sewage sludgeamended soil', $\mathrm{PhD}$ dissertation, Cornell University.

Carpi, A. and Lindberg, S. (1997) 'Sunlight-mediated emission of elemental mercury from soil amended with municipal sewage sludge', Environ. Sci. Technol., Vol. 31, pp. 2085-2091.

Chaney, R.L. (1995) Summary of (1) differences between USDA's views and those of EPA under 40 CFR 503; (2) differences in the views of M.B. McBride and R.L. Chaney regarding the fate of potential effects of heavy metlas in biosolids beneficially used on cropland; and (3) needed research to support long-term biosolids utillization on cropland. Letter from Chaney to A.R. Rubin, J.M. Walker, M.B. McBride and others.

Chaney, R.L. and Ryan, J.A. (1994) Risk Based Standards for Arsenic, Lead and Cadmium in Urban Soils, DECHEMA, Frankfurt, Germany.

Chaney, R.L., Ryan, J.A. and O'Connor, G.A. (1996) 'Organic contaminants in municipal biosolids: risk assessment, quantitative pathways analysis, and current research priorities’, The Science of the Total Environment, Vol. 185, pp. 187-216. 
Chaney, R.L., Ryan, J.A. and O’Connor, G.A. (1997) 'Pathway analysis of terrestrial risks from PCBs in land-applied biosolids based on field measured transfer coefficients', paper presented at the Specialty Conference on Management and Fate of Toxic Organics in Sludge Applied to Land, Copenhagen, Denmark, April 30-May 2, 1997.

Chou, M. (1992) 'Changes in the American diet over the past 20 years', Cereal Foods World, Vol. 36, No. 2, pp. 249-250.

Citizens' Environmental Coalition and Scenic Hudson (1996) Sewage Sludge in Agriculture: Cause for Concern, p. 4.

Cleland, J. (1995) 'Sensitivity analysis for the Part 503 surface water pathway', presentation and handout to the NYS Biosolids Roundtable, Scenic Hudson, Poughkeepsie, NY.

Cornell Cooperative Extension (1997) 'Land Application of Sewage Sludges', Cornell Recommends for Field Crops, Ithaca, NY, pp. 2024.

Cornell Waste Management Instutute (1996) Land Application of Sewage Biosolids, two-hour video. Cornell Resource Center, 7 Business \& Technology Park, Ithaca, NY 14850. (phone: 607 255-2080, fax: 255-9946, email: dist_center@cce.cornell.edu).

Cornell Waste Management Institute (1997a; revised 1999) 'Land application of sewage sludges: the case for caution: recommendations and appraisal of the US EPA's Part 503 sludge rules', working paper, Cornell Waste Management Institute, Rice Hall, Ithaca, NY, USA, 14853.

Cornell Waste Management Institute (1997b) Sludge Land Application: Questions and Answers (on the World Wide Web, http://www.cfe.cornell.edu/ wmi/sludgeques.htm1).

Crommentuijn, G.H. et al. (1994). 'Guidance on the derivation of ecotoxicological criteria for serious soil contamination in view of the intervention value for soil clean-up', Report No. 955001 003, National Institute of Public Health \& the Environment, the Netherlands.

Danish Ministry of Environment and Energy (1996) Statutory Application of Waste Products for Agricultural Purposes, No. 823, Annex. 2.

Dubovi, E. (1997) Cornell University Veterinary Diagnostic Lab, personal communication.

Duff, R.M. (1996) 'A public health perspective on the land application of sewage sludge: review of the US EPA technical support document for the land application of sewage sludge', New Hampshire Bureau of Health Risk Assessment.

Fleming, G.A. (1980) 'Essential micronutrients I. boron and molybdenum', in Davies, B.E. (Editor) Applied Soil Trace Elements, John Wiley and Sons, New York.

Frank, R. et al. (1976) 'Metals in agricultural soils of Ontario', Canadian J. Soil Science, Vol. 56, pp. 181-196.

Giger, W. (1997) 'Occurrence and behaviour of detergent-derived contaminants in sewage sludge', paper presented at the Specialty Conference on Management and Fate of Toxic Organics in Sludge Applied to Land, Copenhagen, Denmark, April 30-May 2, 1997.

Gorlach, E. and Gambus, F. (1992) 'A comparison of sensitivity to the total action of heavy metals in various plant species', Polish J. Soil Science, Vol. 25, No. 2, pp. 207-213.

Heimendinger, J. and Van Duyn, M.S. (1995) 'Dietary behavior change: the challenge of recasting the role of fruit and vegetables in the Amiercan diet', Amer. J. Clinical Nutrition, Vol. 61 (suppl) pp. 1397x-1401s.

Holmgren, G.G.S., Meyer, M.W., Chaney, R.L. and Daniels, R.B. (1993) 'Cadmium, lead, zinc, copper and nickel in agricultural soils of the United States of America', J. Environmental Quality, Vol. 22, pp. 335-348.

Horstman, M. and McLachlan, M.S. (1995) 'Concentrations of polychlorinated dibenzo-p-dioxins (PCDD) and dibenzofurans (PCDF) in urban runoff and household wastewaters', Chemosphere, Vol. 31, pp. 2897-2900.

Ibekwe, A.M., Angle, K.S., Chaney, R.L. and van Berkum, P. (1996) 'Zinc and cadmium toxicity to alfalfa and its microsymbiont', $J$. Environ. Qual., Vol. 25, pp. 1032-1040.

Jacobs, L.W. (Editor) (1989) Selenium in Agriculture and the Environment, Soil Science Society of American Special Publication No. 23, Madison, WI. 
Jansen, P.J.C.M. and Spiejers, G.J.A. (1997) 'Guidance on the derivation of maximum permissible risk levels for human intake of soil contaminents', Report No. 711701 006, National Institute of Public Health \& the Environment, the Netherlands.

Krebs-Smith, S.M., et al. (1995) 'US adults' fruit and vegetable intake, 1989 to 1991: a revised baseline for Healthy People 2000 objective', Amer. J. Public Health, Vol. 85, No. 12, pp. 1623-1629.

Krogmann, U., Boyles, L.S., Martel, C.J. and McComas, K.A. (1997) 'Biosolids and sludge management', Water Envrionment Research, Vol. 69, pp. 534-550.

Kubota, J. and Allaway, W.H. (1972) 'Geographic distribution of trace element problems', in Mortvedt, J.J., et al. (Editors) Micronutrients in Agriculture, Madison, WI: Soil Science Society of America, ppp. 525-554.

Leschber, R. (1997) 'Regulations in Germany for agricultural use of sewage sludge with special regard to toxic organics', paper presented at the Specialty Conference on Management and Fate of Toxic Organics in Sludge Applied to Land, Copenhagen, Denmark, April 30-May 2, 1997.

Logan, T.J. and Traina, S.J. (1993) 'Trace metals in agricultural soils', in Allen, H.E. et al. (Editors) Metals in Groundwater, Lewis Publishers, Chelsea, MI, pp. 309-347.

Lund, L. (1997) Texas Natural Resources Conservation Commission, Office of Air Quality. personal communication.

Madsen, T. (1997) Danish Water Quality Institute, personal communication.

Matthews, P. (Editor) (1996) A Global Atlas of Wastewater Sludge and Biosolids Use and Disposal, International Association on Water Quality, London.

McBride, M.B. (1995) 'Toxic metal accumulation from agricultural use of sludge: are US EPA regulations protective?', J. Environmental Quality, Vol. 24, pp. 5-18. 
McBride, M.B. (1998a) 'Growing food crops on sludge-amended soils: problems with the US EPA method of estimating toxic metal transfer', Environ. Toxicol. and Chem., Vol. 17, pp. 2274-2281.

McBride, M.B. (1998b) 'Soluble trace metals in alkaline stabilized sludge products', J. Environ. Quality, Vol. 27, pp. 578-584.

McBride, M.B. (1998c) personal communication.

McBride, M.B., Richards, B.K., Steenhuis, T., Russo, J.J. and Suave, S. (1997) 'Mobility and solubility of toxic metals and nutrients in soil fifteen years after sludge application', Soil Science, iVol. 162, pp. 487-500..

McGrath, S.P., Chang, A.C., Page, A.L. and Witter, E. (1994) 'Land application of sewage sludge: scientific perspectives of heavy metal loading limits in Europe and the United States', Envir. Rev., Vol. 2, pp. 108-118.

McGrath, S.P., Chaudri, A.M. and Giller, K.E. (1995) 'Long-term effects of metals in sewage sludge on soils, microorganisms and plants', J. Industrial Microbiology, Vol. 14, pp. 94-104.

McLachlan, M.S., Sewart, A.P., Bacon, J.R. and Jones, K.C. (1996) 'Persistence of PCDD/Fs in a sludge-amended soil', Environ. Sci. Technol., Vol. 30, pp. 2567-2571.

Miljøverndepartementet (1997) Forskrift om avløpsslam, (Norwegian standards).

Mumma, R.O., Raupach, D.C., Waldman, J., Tong, S.S.C., Jacobs, M.L., Babish, J.G., Hotchkiss, J.H., Wszolek, P.C., Gutenman, W.H., Bache, C.A. and Lisk, D.J. (1984) 'National survey of elements and other constitutents in municipal sewage sludges', Arch. Environ. Contam. Toxic. Vol. 13, pp. 75-83.

Mumma, R.O., Raupach, D.C., Waldman, J., Hotchkiss, J.H., Gutenman, W.H., Bache, C.A. and Lisk, D.J. (1983) Arch. Rnviron. Contam. Toxic, Vol. 12, pp. 581-587.

Munters, W.H. (1996) Netherlands Ministry of Housing, Spatial Planning and Environment, Dept. of Soil Protection, personal communication.

National Research Council (1996) Use of Reclaimed Water and Sludge in Food Crop Production, National Academy Press.

Netherlands Ministry of Housing, Spatial Planning and Environment, Dept. of Soil Protection (1994) Intervention Values and Target Values: Soil Quality Standards, The Hague, the Netherlands.

New York State Dept. of Environmental Conservation (1993) Solid Waste Management Facilities: Revisions/Enhancements to New York State's Waste Management Facilities, 6 NYCRR Part 360.

New York State Dept. of Environmental Conservation (1994) Determination of Soil Cleanup Objectives and Cleanup Levels, Division Technical and Administrative Guidance Memorandum No. 4046.

Nguyen, H.Q. and O'Connor, G.A. (1997) 'Sludge-borne molybdenum activity', in Fourth International Conference on the Biogeochemistry of Trace Elements, University of California, Berkley, June 23-26.

Ontario Ministry of Agriculture, Food and Rural Affairs (1995) Analytical Results, Findings and Recommendations of the 1995 OMAFRA Sewage Biosolids Field Survey.

Ontario Ministry of Environment \& Energy (1996) Guidelines for the Utilization of Biosolids and Other Wastes on Agricultural Land.

Parkhurst, D.F. (1998) 'Arithmetic versus geometric means for environmental concentration data', Environ. Sci. Technol., Vol. 32, pp. 92A-98A.

Pennsylvania State University (1985) NEC-28. 'Criteria and recommendations for land application of sludges in the Northeast', Bulletin 851.

Powelson, D.K. et al. (1991) 'Effects of organic matter on virus transport in unsaturated flow', Appl. Environ. Microbiol., Vol. 57, pp. 2192-2196.

Purves, D. (1985) Trace-element Contamination of the Environment, Elsevier, New York. 
Richards, B.K. (1997) Review of the US EPA Part 503 Risk Assessment groundwater pathway. Presentation to Cornell Sludge Metals Working Group. April 17, 1997.

Richards, B.K., Peverly, J.H., Steenhuis, T.S. and Liebowitz, B.N. (1997) 'Effect of processing mode on trace elements in dewater sludge products', J. Environmental Quality, Vol. pp. 782-788.

Schmidt, J.P. (1997) 'Understanding phytotoxicity thresholds for trace elements in land-applied sewage sludge', J. Environmental Quality, Vol. 26, pp. 4-10.

Shacklette, H.T. and Boergen, J.C. (1984) 'Element concentrations in soils and other surficial materials of the coterminous United States', US Geological Survey Professional Paper 1270, United States Govt. Printing Office. Washington, DC.

Soares, H.M., et al. (1995) 'Evaluating pathogen regrowth in biosolids compost', Biocycle, Vol. 36, No. 6, pp. 70-76.

Stanek, E. and Calabrese, E. (1995) 'Daily estimates of soil ingestion in children', Environmental Health Perspectives, Vol. 103 , No. 3.

Stern, A.H. (1993) 'Monte Carlo analysis of the US EPA model of human exposure to cadmium in sewage sludge through consumption of garden crops', J. Exposure Analysis and Environmental Epidemiology, Vol. 3, pp. 449-469.

Straub, T.M. et al. (1993) 'Hazards from pathogenic microorganisms in land-disposed sewage sludge', Reviews of Environmental Contamination and Toxicology, Vol. 132, pp. 55-91.

Swartjes, F. (1997) personal communication.

Texas Natural Resource Conservation Commission (1996) End-Product Standards for Compost, Office of Air Quality, RG-217.

Texas Natural Resource Conservation Commission (1997) Title 30 Chapter 332.

Thornton and Abrahams (1981) 'Soil ingestion as a pathway of metal intake into grazing livestock', Proc Internat. Conf. on Heavy Metals in the Environment, CEP Consultants, Edinburgh, UK.

Tideström, H. (1997a) Swedish Environmental Protection Agency, personal communication.

Tideström, H. (1997b) 'Swedish regulation on the use of sewage sludge in agriculture: why is it important to use sludge as a fertilizer in agriculture?', Specialty Conference on Management and Fate of Toxic Organics in Sludge Applied to Land, Copenhagen, Denmark, April 30-May 2, 1997.

USDA (1996) Dietary Guidelines for Americans, Home \& Garden Bulletin No. 232.

UK Dept. of the Environment (1995) Code of Practice for Agricultural Use of Sewage Sludge, HMSO, London.

US EPA (1990) National Sewage Sludge Survey; Availability of Information and Data, and Anticipated Impacts of Proposed Regulations, proposed rule, Title 40 of the Code of Federal Regulations, Part 503. Fed. Regist., 55, $47210-47238$.

US EPA (1992) Technical Support Document for Land Application of Sewage Sludge, Document No. EPA-822/R0-93-001a.

US EPA (1993) The Standards for the Use or Disposal of Sewage Sludge, Title 40 of the Code of Federal Regulations, Part 503.

US EPA (1994) A Plain English Guide to the EPA Part 503 Biosolids Rule, Office of Wastewater Management, EPA/832/R-93/003.

US EPA (1995) A Guide to the Biosolids Risk Assessment for the EPA Part 503 Rule, Office of Wastewater Management, EPA/8332//B93-005.

US EPA (1996a) Evaluation of Candidate Pollutants for the Round Two Sewage Sludge Regulation, Office of Wastewater Management.

US EPA (1996b) Soil Screening Guidance, EPA Tech. Background Document No. 9355.4-23.

US EPA (1996c) Technical Support Document for the Round Two Sewage Sludge Pollutants, Office of Water, EPA-822/R-96-003. 
US GAO (1994) Nuclear Regulation: Action Needed to Control Radioactive Contamination at Sewage Treatment Plants, GAO/RCED94-133.

van den Berg, R. (1994) 'Human exposure to soil contamination: a qualitative and quantitative analysis towards proposals for human toxicological intervention values', Report No. 725201011, National Institute of Public Health and the Environment, the Netherlands.

van den Berg, R. et al. (1993) 'Risk assessment of contaminated soil: proposals for adjusted, toxicologically based Dutch soil clean-up criteria', Contaminated Soil '93, Kluwer Academic Publishers, the Netherlands, pp. 349-364.

Water Environment Federation (1996) Biosolids Recycling: Grounded in Sound Science, Alexandria, VA.

Webber, M.D. and Nichols, J.A. (1995) Organic and Metal Contaminants in Canadian Municipal Sludges and a Sludge Compost, Wastewater Technology Centre.

Witter, E. (1996) 'Towards zero accumulation of heavy metals in soils', Fertilizer Research, Vol. 43, pp. 225-233. 